\title{
Çocuklarda akut çıkıklara yaklaşım
}

\section{Management of acute dislocations in children}

\author{
Serkan Erkuş, Önder Kalenderer
}

İzmir Tepecik Eğitim ve Araştırma Hastanesi, Ortopedi ve Travmatoloji, İzmir

\begin{abstract}
Çocuklarda eklem çıkıkları, kırıklara göre daha nadir görülen yaralanmalardır. Çıkık mekanizmaları düşünüldüğünde, oluşan enerji çıkık oluşturuncaya kadar daha sık olarak büyüme plağı kırıklarına ve yaralanmalarına neden olmaktadır. Basit düşmelerle oluşabileceği gibi araç içi ve dışı yüksek enerjili yaralanmalarla da oluşabilir. En sık, dirsek çıkıkları görülmektedir. Çıkıklara en kısa zamanda müdahale edilmelidir. Çıkıkların çoğu kapalı redüksiyon manevraları ile kolaylıkla redükte edilebilir. Ancak redüksiyonun başarısız olduğu olgularda; instabilite, açık çıkık, damar-sinir yaralanması ve eklem içinde sıkışan kemik parçaların varlığında, cerrahi tedaviler uygulanmalıdır.
\end{abstract}

Anahtar sözcükler: çocuk; çıkık; kırıklı çıkıklar; akut
Dislocations in children are rarer injuries than fractures. When the dislocation mechanisms are considered, the resulting energy causes growth plate fractures and injuries more frequently until dislocation occurs. It can occur with simple falls or with high-energy injuries both inside and outside the vehicle. The elbow dislocations are the most common. The dislocation should be intervened as soon as possible. Most of them can easily be reduced by closed reduction maneuvers. However, in cases of reduction failure, surgical treatment should be performed for instability, open dislocation, neurovascular injury and presence of bone fragments trapped within the joint.

Key words: children; dislocation; fractured dislocations; acute

\section{AKROMIYOKLAVIKÜLER EKLEM (AKE) ÇIKIKLARI}

AKE çıkıkları oldukça nadir görülen yaralanmalardır. Kontakt sporları ile uğraşan adolesanlarda genelde direkt travmalarla ortaya çıkar. ${ }^{[2]}$ Genelde konservatif yöntemlerle (omuz-kol askısı) tedavi edilir (Şekil 1).

\section{TRAVMATIK OMUZ ÇIKIKLARI}

Oldukça nadir görülen yaralanmalardır. Kontakt sporları ile uğraşan adolesanlarda nadiren görülür. Atravmatik olandan ve istemli çıkıklardan mutlaka ayırt edilmeleri gerekir. En sık görülen öne omuz çıkığında anteroinferior glenohumeral bağ ve anterior labrum yaralanır. Bu yaralanma "Bankart lezyonu" olarak tanımlanır. Travmanın şiddetine bağı ılarak

- İletişim adresi: Doç. Dr. Önder Kalenderer, İzmir Tepecik Eğitim ve Araştırma Hastanesi, Güney Mah. Gaziler Cad. No: 468 Konak, İzmir Tel: 0532 - 2971067 e-posta: okalenderer@gmail.com

- Geliş tarihi: 9 Kasım $2018 \quad$ Kabul tarihi: 9 Kasım 2018 


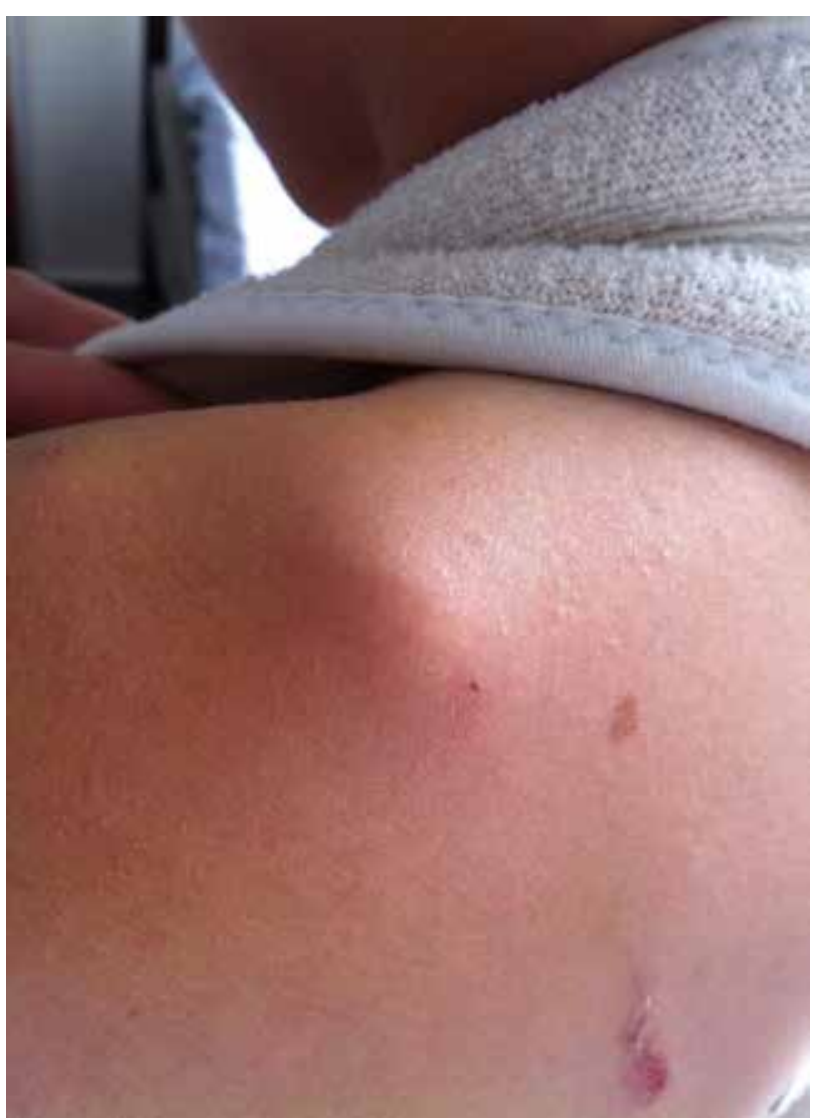

Şekil 1. AKE çıkığına bağlı cilt irritasyonu.

humerus başının posterior yüzünde defekt oluşur. Bu durum da "Hill-Sachs lezyonu" olarak tanımlanır. Öne omuz çıkığı; kol abduksiyon, ekstansiyon ve dış rotasyonda düşme sonucu indirekt kuvvetlerle oluşur. Arkaya omuz çıkığı genelde direkt travmalar sonucu ortaya çıkar. İnferior glenohumeral eklem çıkığı ise "luxatio erecta" olarak tanımlanır. ${ }^{[3]}$

Öne omuz çıkığında, hasta ağrı ile ve kol hafifçe dış rotasyon ve abduksiyonda kliniğe başvurur. Akromiyonun altı boş görülür ve humerus başı anteriorda palpe edilir. Damar sinir muayenesi hasta geldiği anda dikkatlice yapılmalıdır. Radyal, median, ulnar, aksiller ve muskülokutanöz sinirlere bakılmalıdır. Öne çıkıkta en sık zedelenen sinir aksiller sinirdir. Bu siniri muayene ederken deltoid kas gücünü değerlendirmek yerine duyu muayenesi daha değerlidir. ${ }^{[4]}$

Genel anestezi altında kapalı redüksiyon ile tedavi uygulanmalıdır. Dirsek fleksiyonda, kol abduksiyonda iken uzunlamasına traksiyon uygulanır. Hafif iç ve dış rotasyon manevraları ile nazikçe çıkık redükte edilebilir. Koltuk altına hekim kendi topuğunu yerleştirerek de aynı manevra ile redüksiyon yapabilir. Bu yöntem "Hipokrat tekniği” olarak bilinir. Bir başka redüksiyon yöntemi ise "Stimson yöntemi"dir. Hasta muayene masasına yüzükoyun olarak yatırılır. El bileğine ağırlık bağlanarak ya da traksiyon uygulanarak redüksiyon elde edilir.

Omuz çıkıklarının en önemli komplikasyonları; iyatrojenik kırıklar, damar-sinir yaralanması, humerus başının osteonekrozu ve tekrarlayıcı (rekürrent) omuz instabilitesidir (en sık).

\section{IZOLE DIRSEK ÇIKIKLARI VE MEDIYAL EPIKONDIL KIRIĞININ EŞLIK ETTIĞi DIRSEK ÇIKIKLARI}

Dirsek çıkıkları çocukluk çağında nadir görülen yaralanmalardır. ${ }^{[5]}$ Genelde mediyal epikondil, radius proksimal, olekranon ve koronoid çıkıntı kırıkları ile birlikte görülür. Dirsek yaralanmaları yaklaşık \%3-6 oranında ve genelde adolesan yaş grubunda (10-15 yaş arası) görülür. Erkek çocuklarda kızlara göre üç kat daha sıktır.

Genelde dirsek ekstansiyonda gergin el üzerine düşmekle oluşur. Öne veya arkaya çıkık şeklinde olabilir. Öne çıkık dirsek, fleksiyonda direkt darbeyle oluşur; $\% 50$ oranında izole dirsek çıkığı görülür; \%50 oranında ise mediyal epikondil kırığı, nadiren de radius boyun kırığı (Şekil 2) çıkığa eşlik eder ve genelde eklem içi yerleşimlidir (Şekil 3). Eklem içinde kalan mediyal epikondil redüksiyonu engeller. ${ }^{[6]}$ Nadiren brakiyal arter ve median sinir sıkışarak damar sinir yaralanması oluşturabilir. Sıklıkla ve özellikle de mediyal epikondilin kırık olduğu durumlarda ulnar sinir yaralanması görülür.

Dirsek çıkıkları humerus distali ile proksimal radyoulnar eklem ilişkisine göre sınıflandırılır. En yaygın olanı posterolateral tip dirsek çıkıklarıdır. En nadir tipi ise anterior çıkıktır. Posteromediyal ve diverjan tip dirsek çıkıkları da vardır. ${ }^{[7]}$

Dirsek şiş ve ağrlıdır. Dirsek hareketleri kısıtlı ve ağrılıdır. Çocuklar dirseklerini genelde fleksiyonda tutarlar. Önkol genelde kısalmış gibi görülür. Mutlaka ayrıntılı damar-sinir muayenesi yapılmalıdır. Sinir yaralanmaları genelde "nöropraksi” şeklindedir ve kendiliğinden düzelir.

İlk değerlendirme olarak, ön-arka ve yan dirsek grafileri çekilmelidir (Şekil 4). Kırık varlığını araştırmak için ilave önkol grafisi de mutlaka çekilmelidir. Şüphe duyulan ya da net tanı koyulamayan olgularda, karşı dirsek görüntülemesi ile karşılaştırma yapılabilir.

Kapalı redüksiyon ile çoğu dirsek çıkığı redükte edilebilir (Şekil 5). Dirsek fleksiyonda traksiyon yapılırken önkol pronasyon ve supinasyona zorlanarak çıkık kolaylıkla redükte edilebilir. Eklem içine sıkışan mediyal epikondil; dirsek fleksiyona, valgusa zorlanırken 


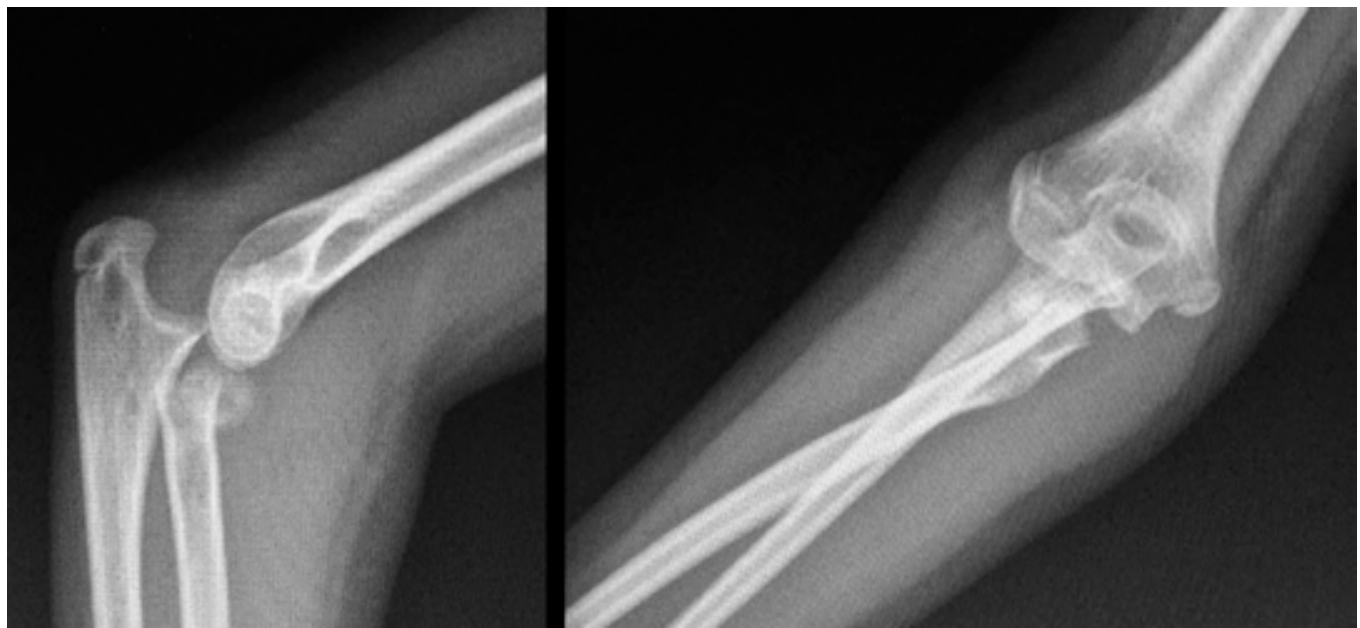

Şekil 2. Dirsek çıkığı ve radius boyun kırı̆̆ı.

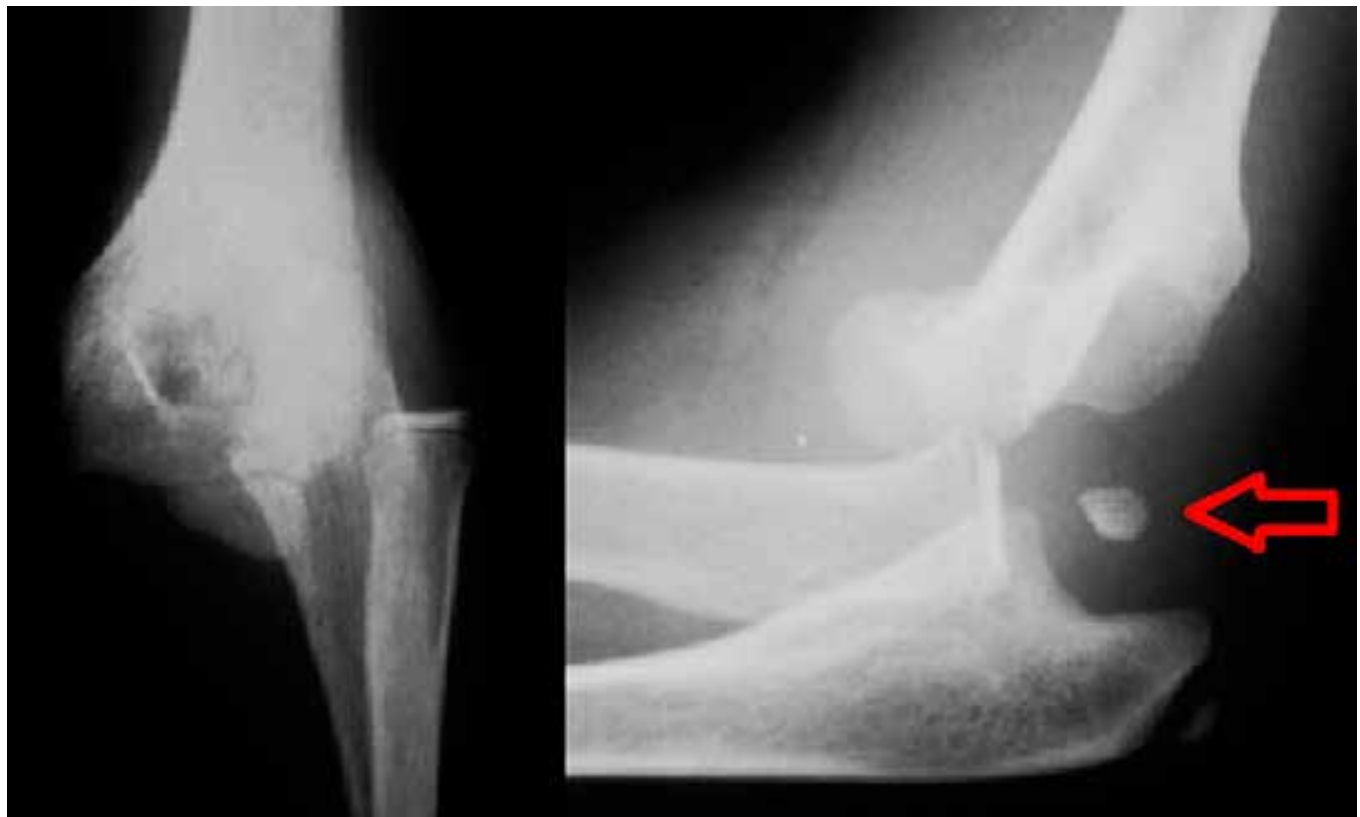

Şekil 3. Mediyal epikondil kırığı ile birlikte dirsek çıkığı.

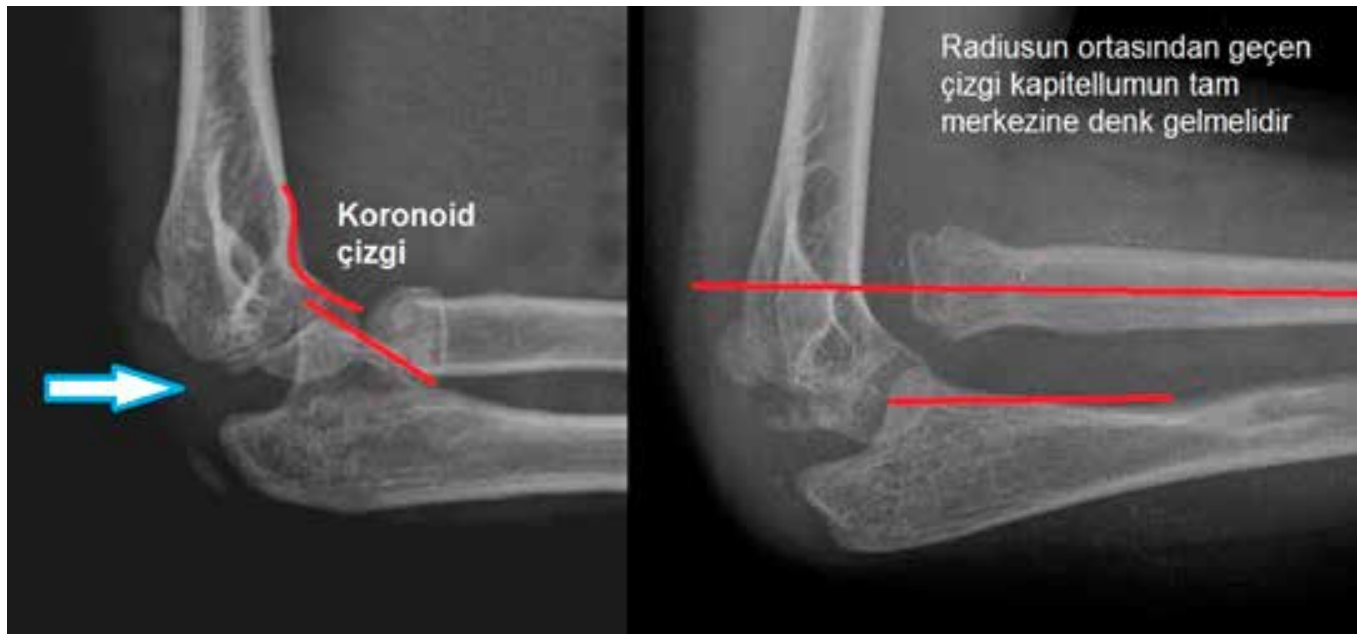

Şekil 4. Dirsek çıkıklarında radyolojik normal çizimler bozulur. 


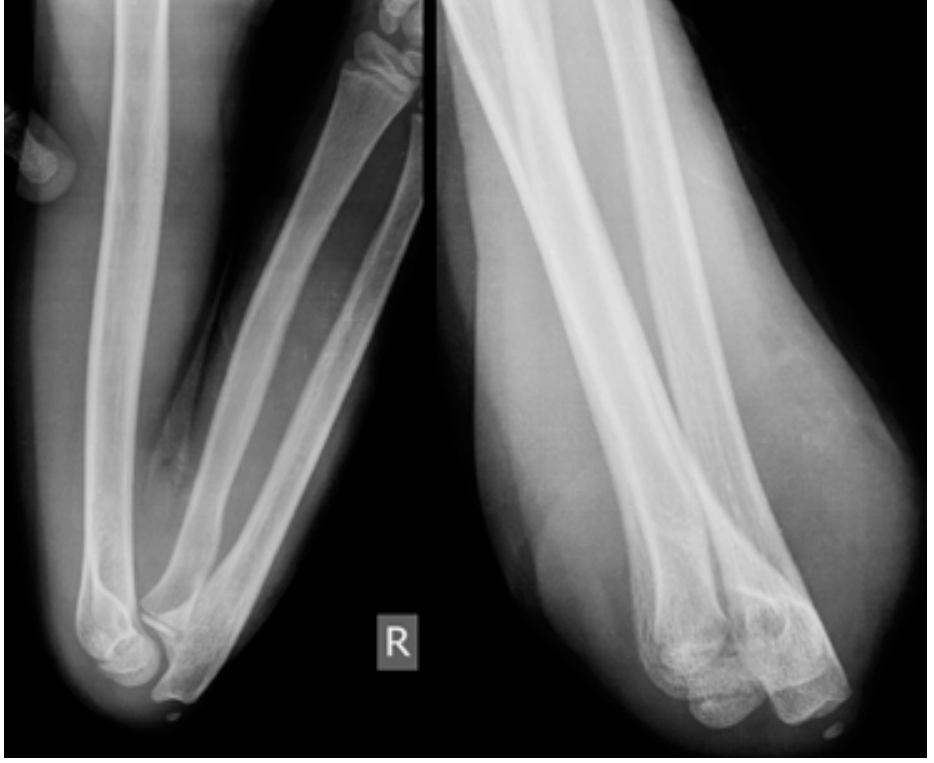

Şekil 5. Instabil çıkıkta aşırı fleksiyonda dirsek çıkı̆̆ı redüksiyonu.

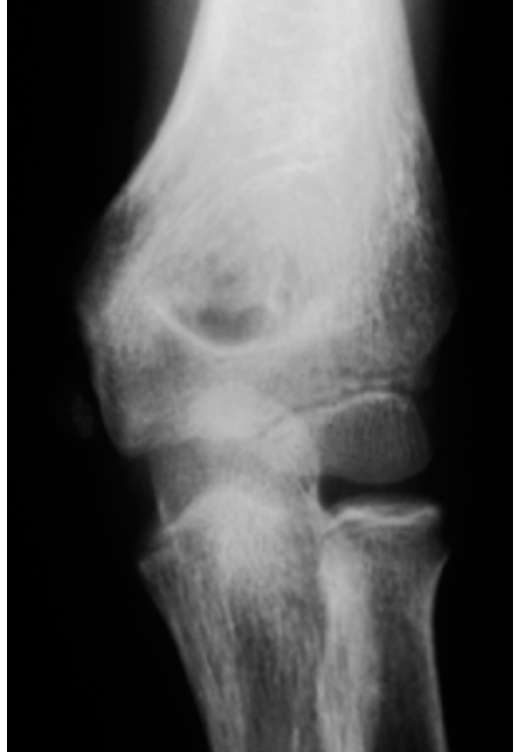

Şekil 6. Mediyal epikondil kırıklı dirsek çıkığının redüksiyon sonrası ön-arka grafisi.

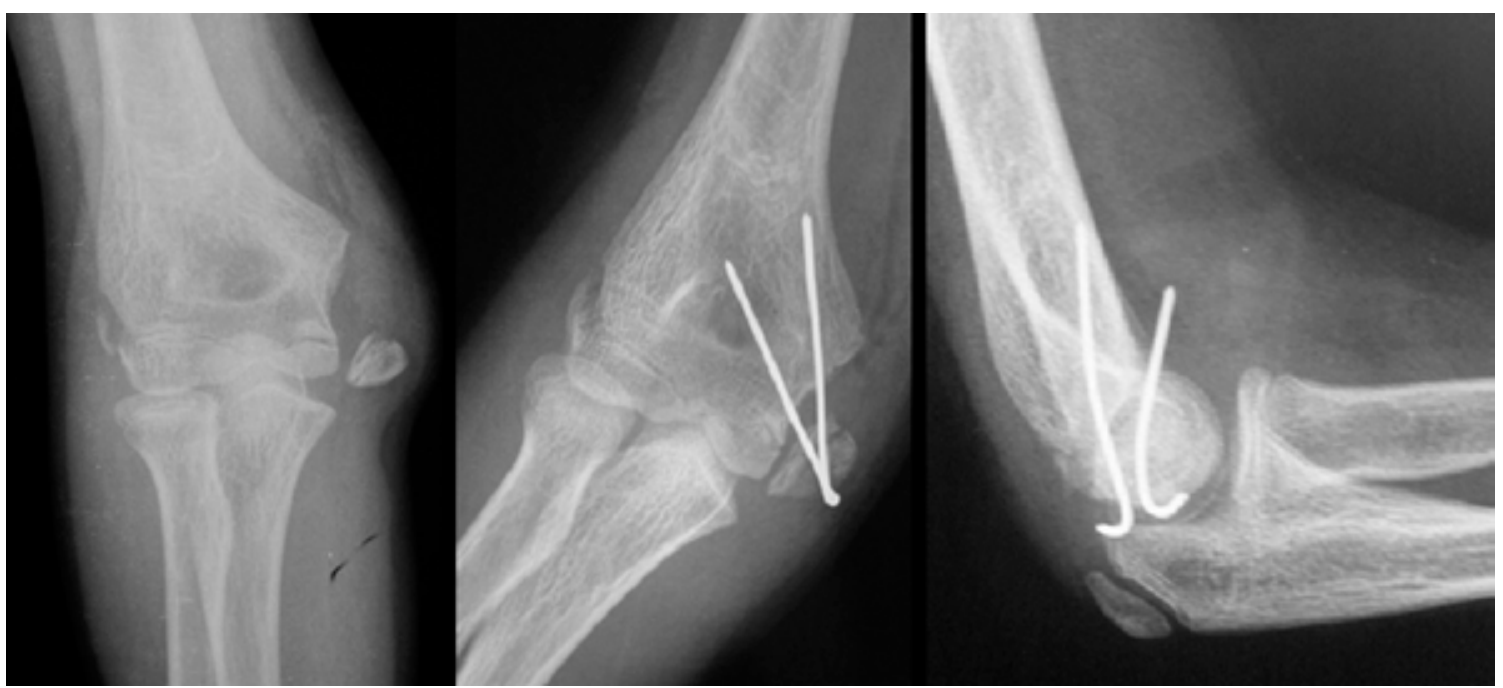

Şekil 7. Dirsek çıkığı ve mediyal epikondil kırığında K-telleriyle açık redüksiyon ve internal tespit.

supinasyon ile eklem dışına çıkarılabilir (Şekil 6). Redüksiyon sonrası mutlaka dirsek hareketleri kontrol edilmelidir. Ardından dirsek $90^{\circ}$ fleksiyonda ve önkol supinasyonda uzun kol alçı ateli uygulanmalıdır. İzole çıkıklarda 1-2 hafta, kırıklı çıkıklarda 3-4 hafta atel uygulanması yeterlidir.

Mediyal epikondil eklem içine sıkıştıysa, açık çıkıksa, kapalı redüksiyon başarılı değilse veya redüksiyon sonrası dirsek stabil değilse açık redüksiyon uygulanmalıdır. ${ }^{[8]}$ Dirsek mediyal insizyonu ile açık redüksiyon yapilır. Mediyal epikondil Kirschner teli (K-teli) ile tespit edilebilir (Şekil 7). Çocuklarda çok nadiren "terrible triad" denilen dirseğin çok yüksek enerjili yaralanmaları da oluşabilir (Şekil 8). Bu hastalarda, radius boynunda ve koronoid çıkıntıda dirsek eklemi çıkığına eşlik eden kırık vardır. Oldukça instabil yaralanmalardır ve kapaIı redüksiyon manevraları başarısızdır. Acil koşullarda açık redüksiyon ve kırıkların tespiti gerekir (Şekil 9).

Saf radius başı çıkıkları oldukça nadirdir (Şekil 10). Kapalı redüksiyonun başarılı olunamadığı olgularda yumuşak doku interpozisyonu olabilir ve cerrahi olarak açık redüksiyon gerekir (Şekil 11). 


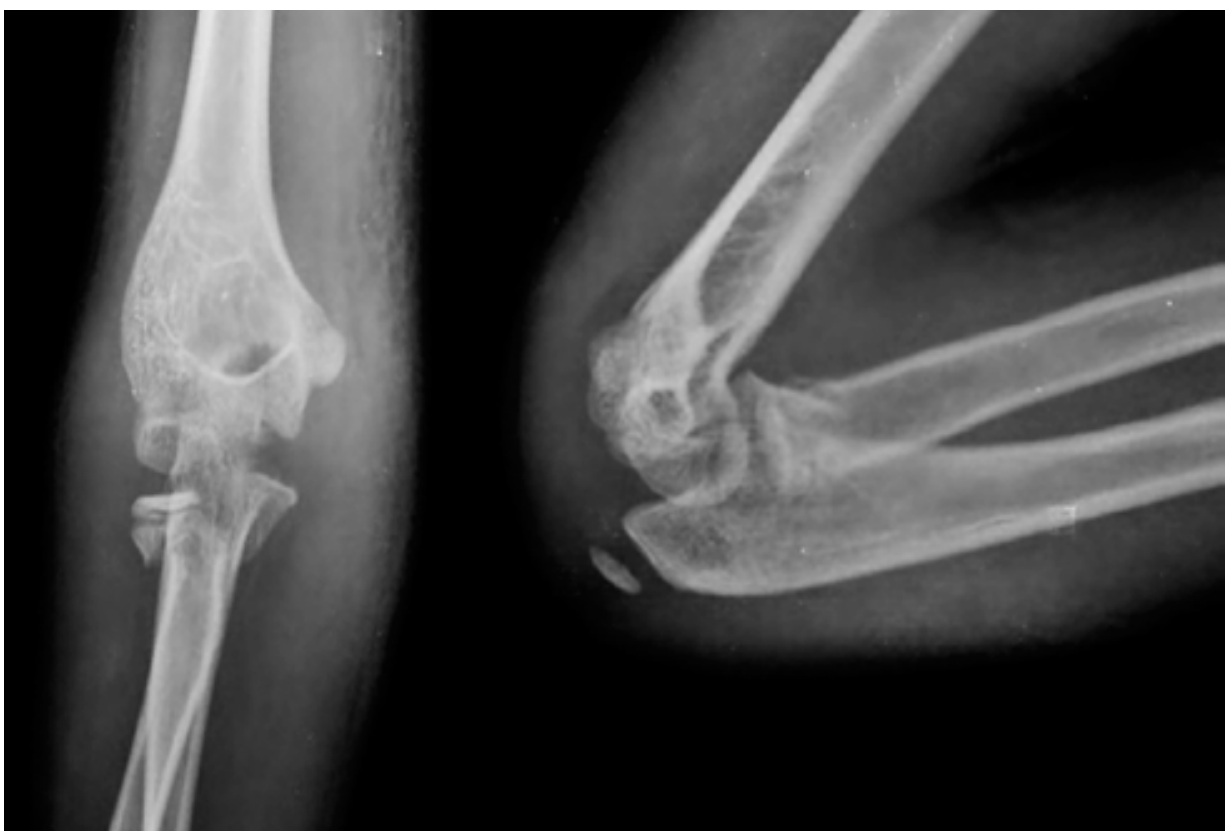

Şekil 8. Terrible triad (radius boyun kırı̆̆ı, dirsek çıkığı ve koronoid proses kırı̆̆ı).

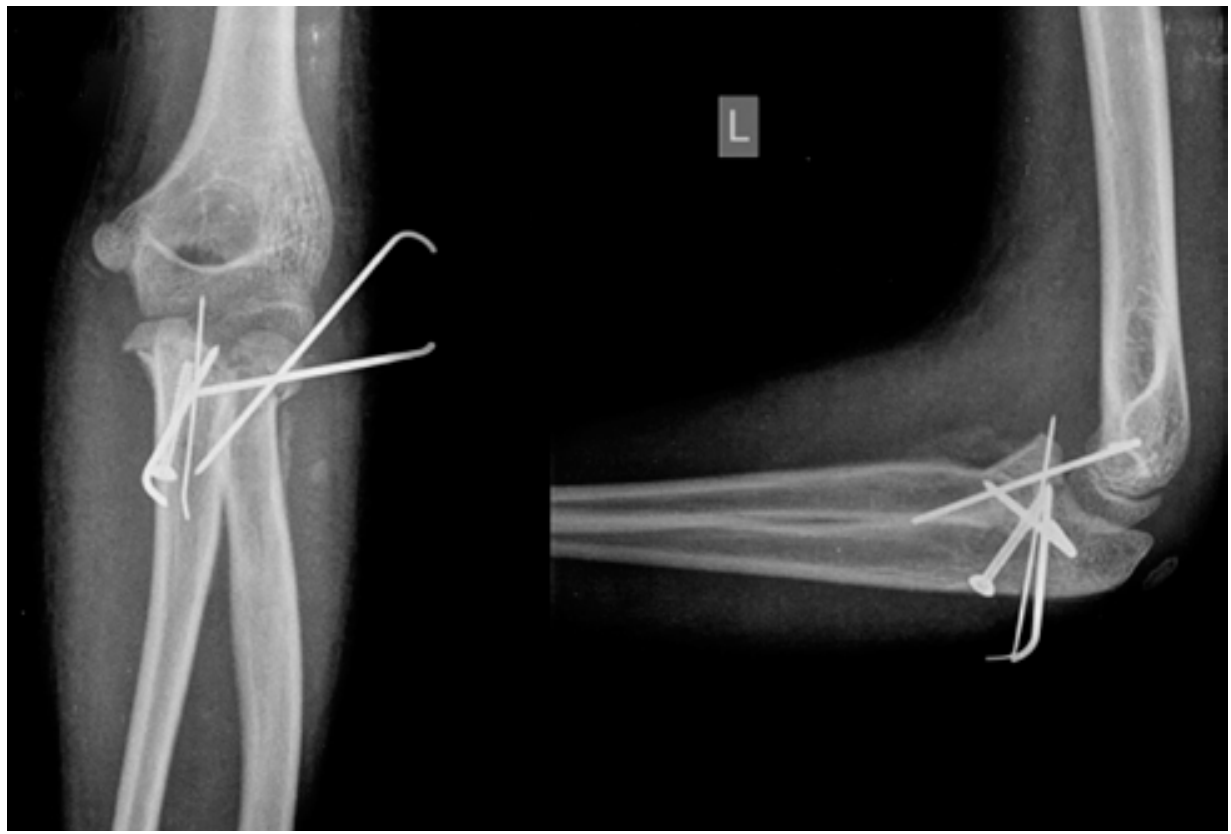

Şekil 9. Terrible triad nedeniyle açık redüksiyon ve internal tespit sonrası ön-arka ve yan dirsek grafileri.

Adolesan yaş grubunda çok nadir de olsa, tedavi edilmemiş ve gecikmiş çıkıklar gelebilir (Şekil 12). Bu tür olgularda üç aya kadar dirsek hareketinin kazanılabilmesi için olekranon osteotomisini takiben açık redüksiyon ve kırık varsa tespiti yapılabilir (Şekil 13). Ancak, hasta ve yakınlarına sonucun başarısı hakkında çok ümit verilmemelidir.
Dirsek çıkı̆̆ı sonrası en önemli komplikasyon, heterotopik ossifikasyon ve eklem sertliğidir (Şekil 14). Bu nedenle olabildiğince nazik redüksiyon yapılmalı, atel süresi kısa tutulmalı ve en kısa sürede aktif dirsek hareketlerine zorlanmadan başlanmalıdır. Pasif egzersizlerin heterotopik ossifikasyonu arttıracağı unutulmamalıdır. 


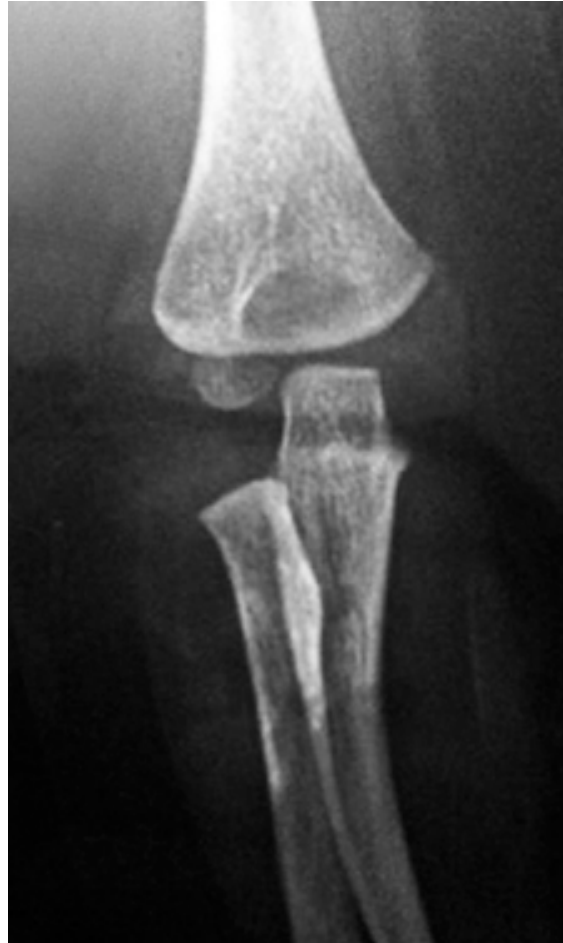

Şekil 10. Saf radius başı çıkı̆̆ı.

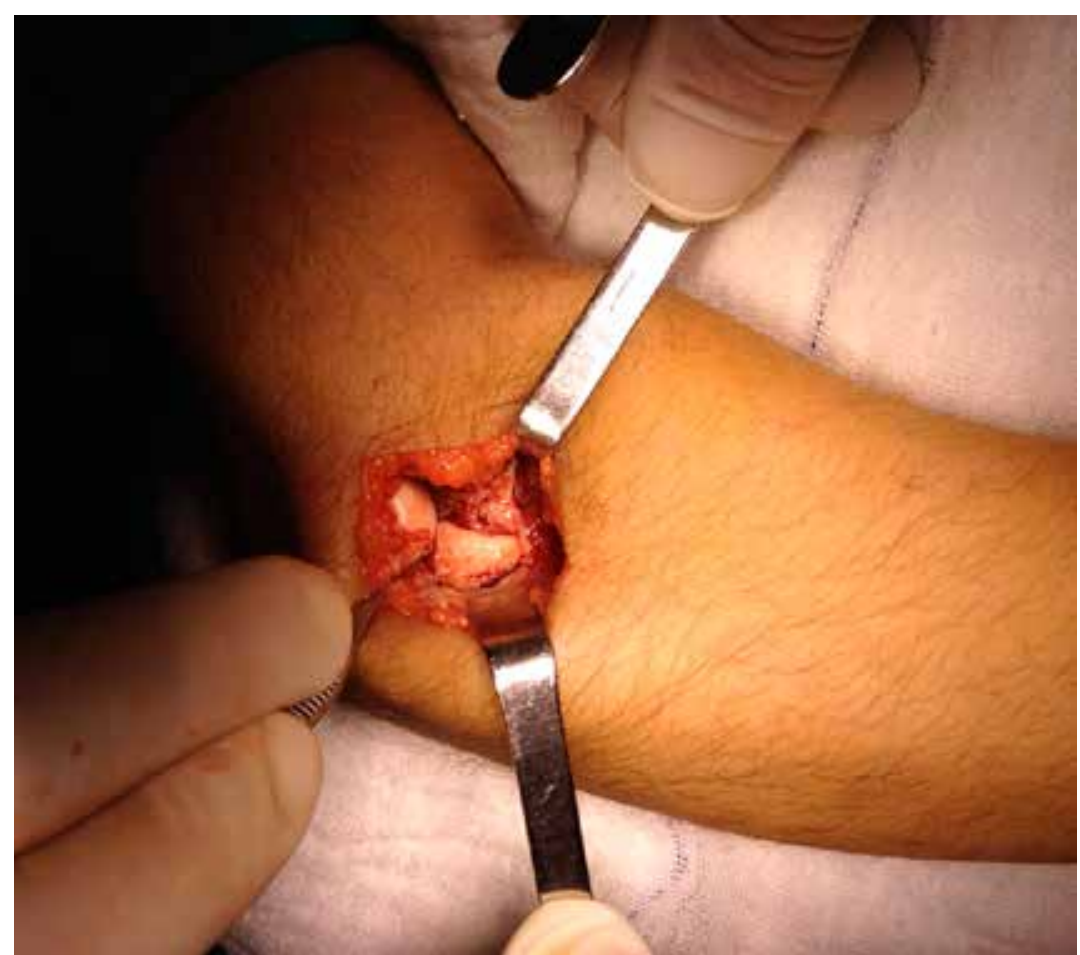

Şekil 11. Radius başının redüksiyonuna engel olan yumuşak doku interpozisyonu ve çıkık görünümü.

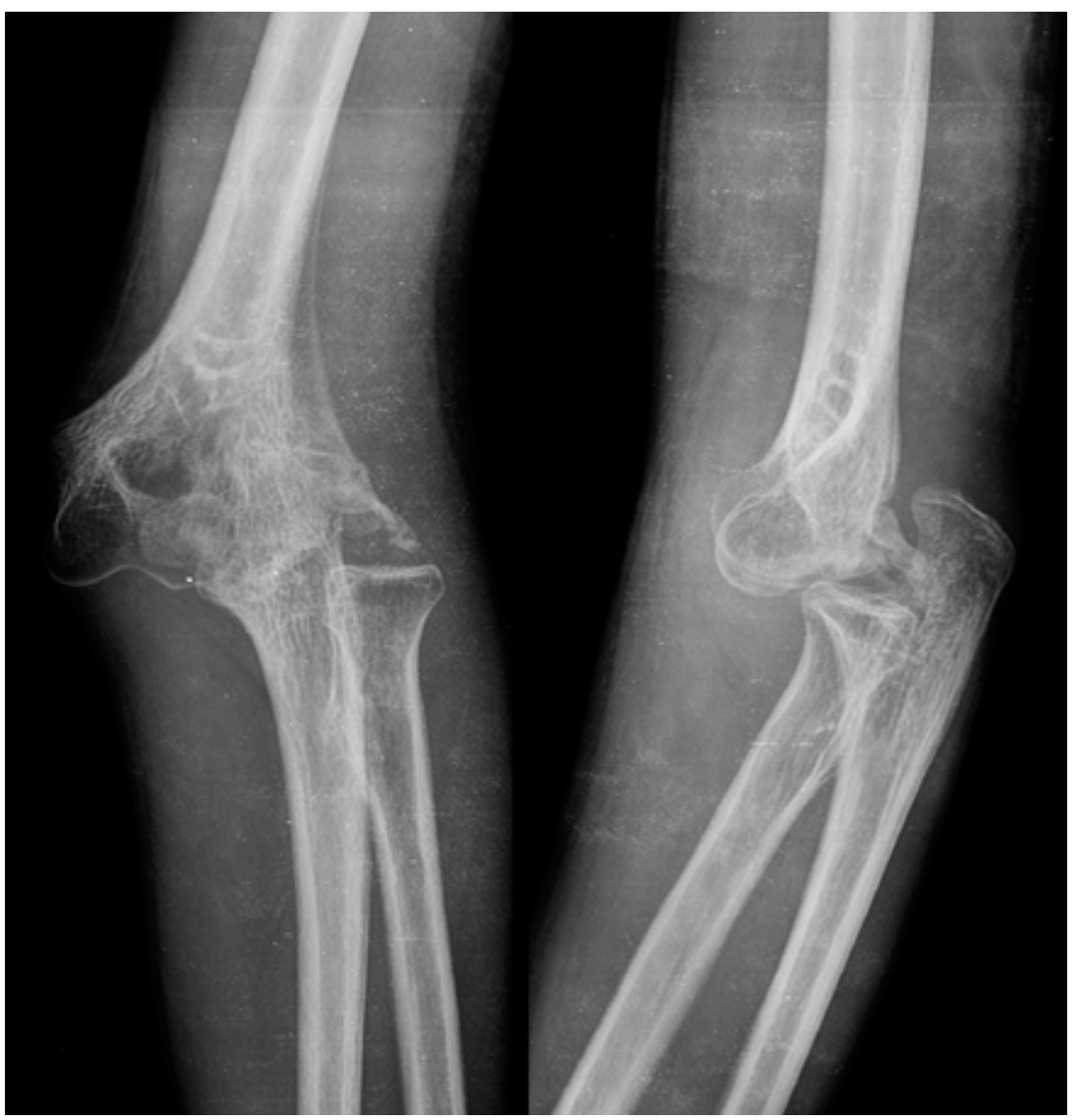

Şekil 12. İki aylık mediyal epikondilin eklem içine sıkıştığı, dirseğin ekstansiyonda kilitlendiği dirsek çıkığı. 


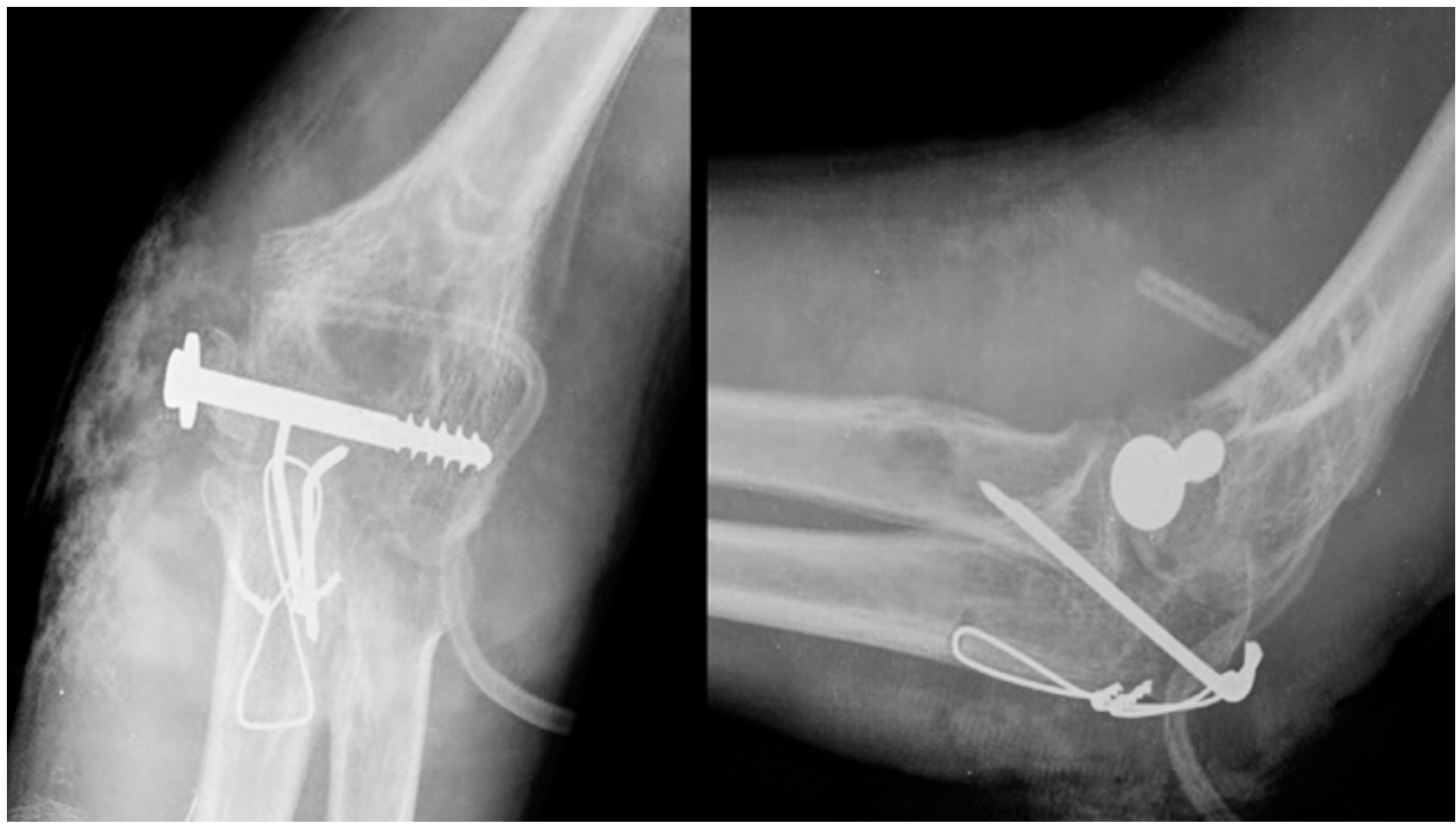

Şekil 13. Olekranon osteotomisi ile açık redüksiyon ve kırık olan mediyal epikondilin vida ile tespiti.

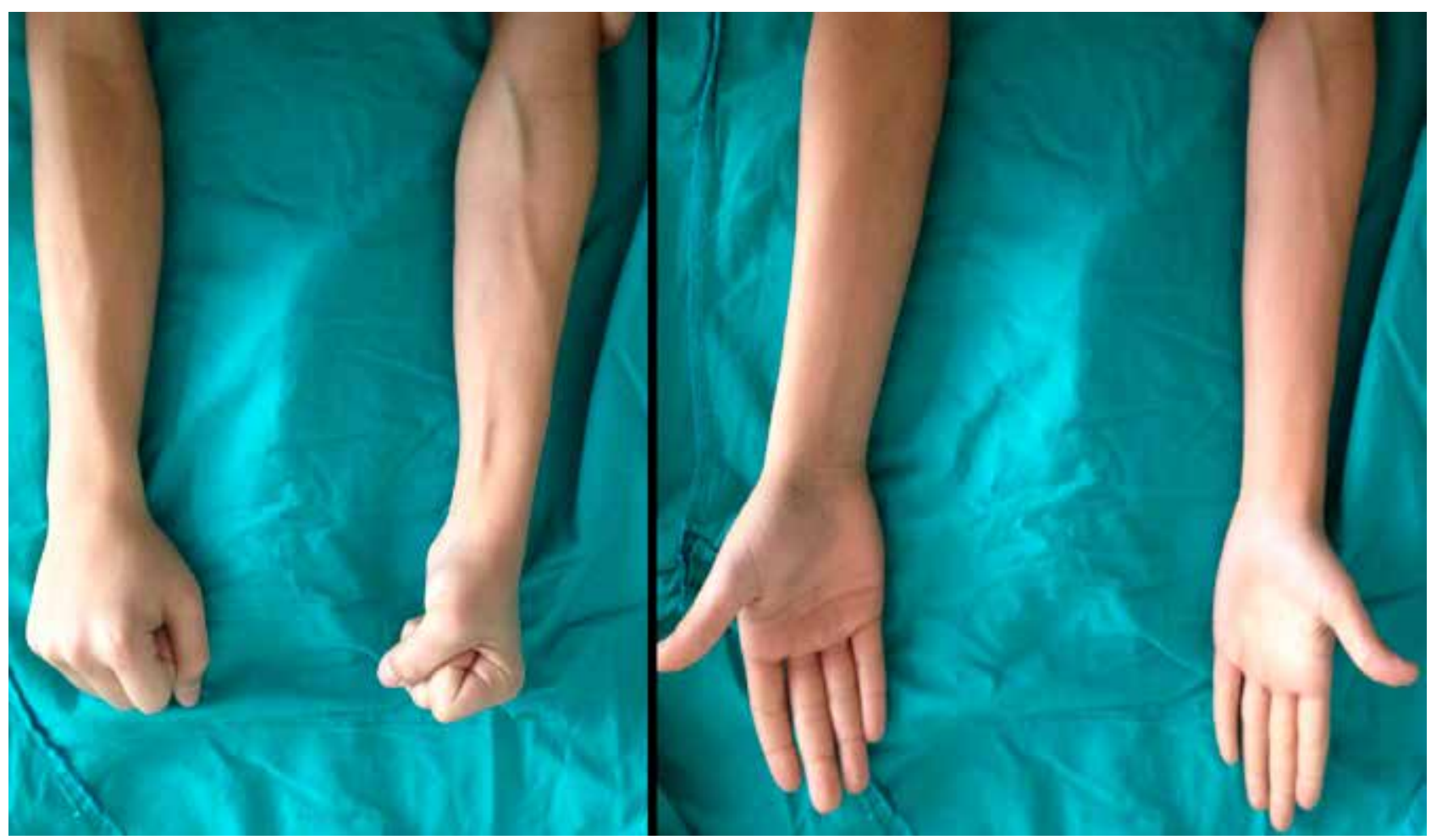

Şekil 14. Dirsek çıkığı sonrası önkol pronasyon ve supinasyon kısıtlılı̆̆ı. 


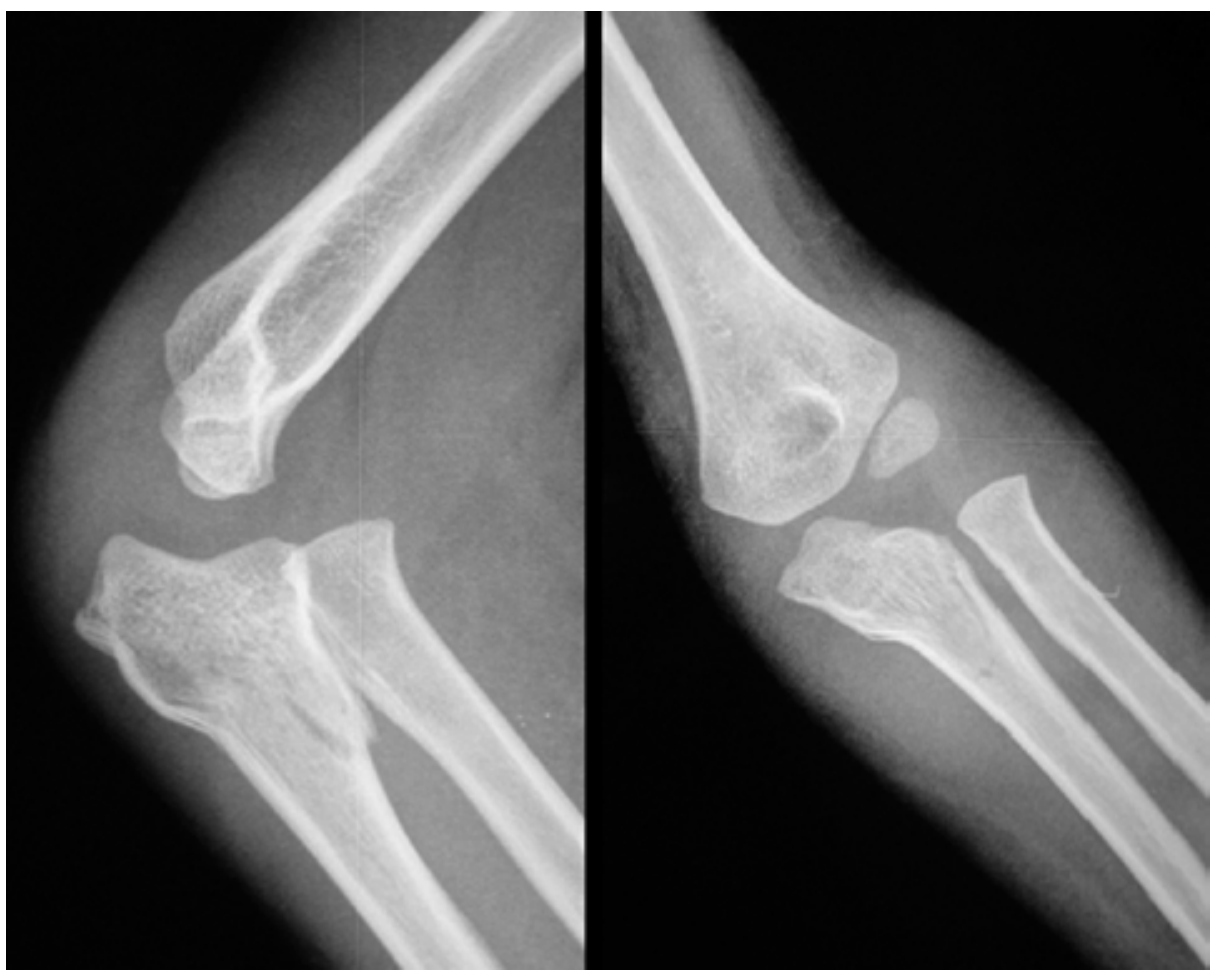

Şekil 15. Olekranon proksimal kırığı ile birlikte radius başının öne çıkığı (Bado Tip I, Monteggia kırıklı çıkı̆̆ı).

\section{MONTEGGIA KIRIKLI ÇIKIKLARI}

Proksimal ulna kırığının eşlik ettiği radius başı çıkığı olarak tanımlanır; 5-10 yaşları arası sık görülen yaralanmalardır. ${ }^{\left[{ }^{9]}\right.}$ Erkek çocuklarda daha sık görülür.

Monteggia kırıkları, radius başının yönüne göre Bado sınıflaması ile sınıflandırılır. ${ }^{[10]}$

\section{Bado Sınıflaması}

Tip I: Apeksi anteriorda olan proksimal ulna kırığı ile birlikte radius başının öne çıkığı (Şekil 15).

Tip II: Apeksi posteriorda olan proksimal ulna kırığı ile birlikte radius başının arkaya çıkığı.

Tip III: Apeksi lateral proksimal ulna kırı̆g ile birlikte radius başının laterale çıkığı.

Tip IV: Aynı seviyede proksimal radius ve ulna kırığı ile birlikte radius başının öne çıkı̆̆ı.

Hasta genelde ağrılı, şiş ve belirgin bir önkol ve dirsek deformitesi ile acil servise başvurur. Önkol rotasyonları ve dirsek fleksiyon ve ekstansiyonu çok ağrılı ve kısıtlıdır. Radius başı genelde çıkık yönünde palpe edilir. Damar-sinir muayenesi; özellikle posterior interosseöz sinir muayenesi, dikkatlice yapılmalıdır; \%10 olguda bu sinir "nöropraksi" şeklinde yaralanabilir ve genelde kendiliğinden düzelir.

Monteggia kırıklı çıkıklarında uygun pozisyonda dirsek ve önkol grafisi çekmek oldukça önemlidir. Dirsek grafisinin çekilmediği veya standart grafilerin çekilemediği olgularda atlanmış radius başı çıkıkları ile karşılaşılabilir. Grafilerde radyokapitellar ilişki mutlaka iyi bir şekilde değerlendirilmelidir. Yan grafilerde radius cisminden geçen çizgi kapitellumun merkezinden geçmelidir (Şekil 4).

Monteggia kırıklarının çoğu konservatif yöntemlerle tedavi edilebilir (Şekil 16). ${ }^{[9]}$ Ulnadaki açılanmanın düzeltilmesi ve ulna uzunluğunun sağlanması temel noktadır. Uzunlamasına traksiyon yapilırken yapılan ulna redüksiyon manevrası, genelde radius başının spontan redüksiyonunu sağlar. Bado Tip I, II ve III kırıklarda ulna redüksiyonu yapılır ve ulna uzunluğu sağlanırsa radius başı stabil olarak redükte olur. Sadece Bado Tip I kırıklarda, dirsek fleksiyonu da radius başının redüksiyonunu sağlayabilir. Bado Tip I kırıklarda, interosseöz membranı germek ve biseps kasının deforme edici gücünü azaltmak için dirsek $110^{\circ}$ fleksiyonda ve önkol supinasyonda uzun kol alçı uygulanmalıdır. Bado Tip 


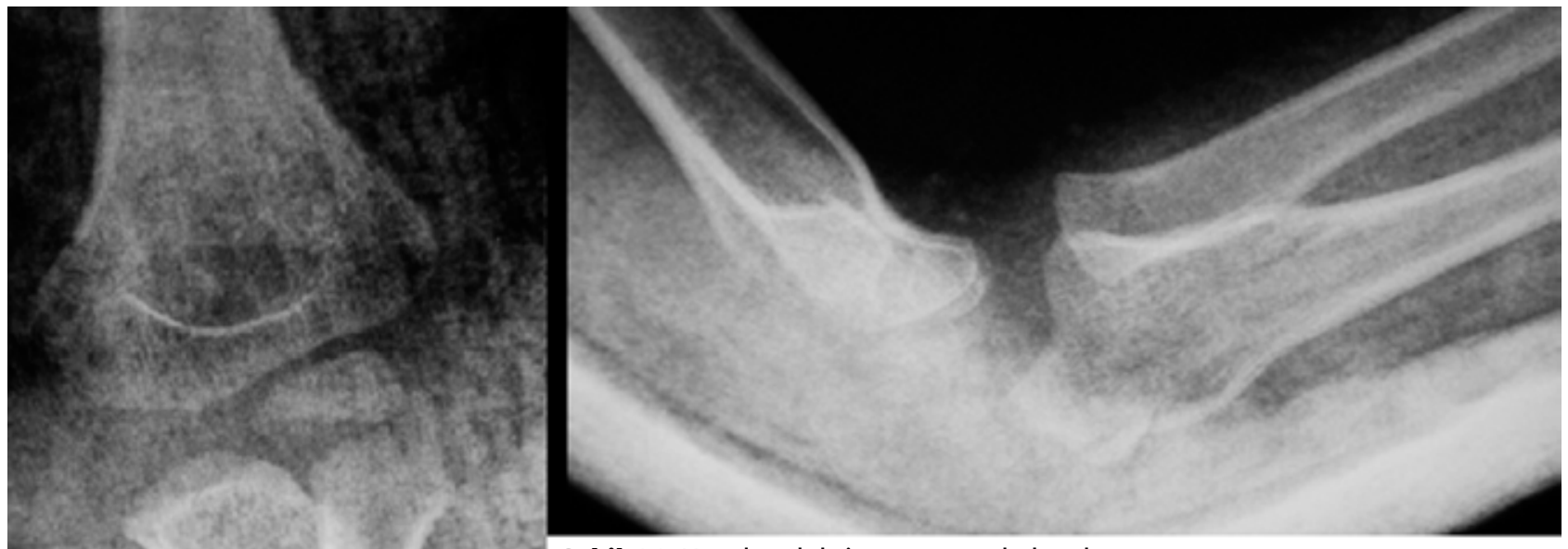

Şekil 16. Kapalı redüksiyon ve uzun kol atel sonrası.

II ve III kırıklarda dirsek ekstansiyonda uzun kol alçı yapılmalıdır.

Kapalı redüksiyonun başarılı olmadığı Bado Tip I, II, III olgularda (radius başı redükte olmuyorsa ve proksimal ulna deformitesi düzeltilemiyor ve ulna uzunluğu sağlanamıyorsa), 10 yaşından büyük çocuklarda, açık kırıklarda ve Bado Tip IV kırıklarda cerrahi tedavi endikasyonu vardır (Şekil 17). ${ }^{[9]}$ Ulna redüksiyon sonrası, gergi bandı yöntemiyle, plak vidayla veya intramedüller titanyum elastik çivileri ile tespit edilir (Şekil 18). $\mathrm{Bu}$ sırada radius başı genelde kendiliğinden redükte olur. Başarılı olunamayan durumlarda veya gecikmiş olgularda radius başı açık veya kapalı olarak redükte edilir. Nadiren radius başının redüksiyonuna engel "annüler bă̆" yırtığına bağlı gelişen "düğme iliği deformitesi” olabilir. Kronik olgularda annüler bağ yırtığı için bağ rekonstrüksiyonu yapılabilir. Stabilite sağlanamıyorsa radyokapitellar K-teli ile redüksiyon korunmaya çalışıır.

Monteggia kırıklarında en temel sorun radius başı çıkığının atlanması veya takiplerde ulna uzunluğunun kaybına bağlı ilerleyici çıkık oluşmasıdır (Şekil 19). Cerrahi tedavi sonrası bile tekrarlayan radius başı çıkıkları oluşabilir.

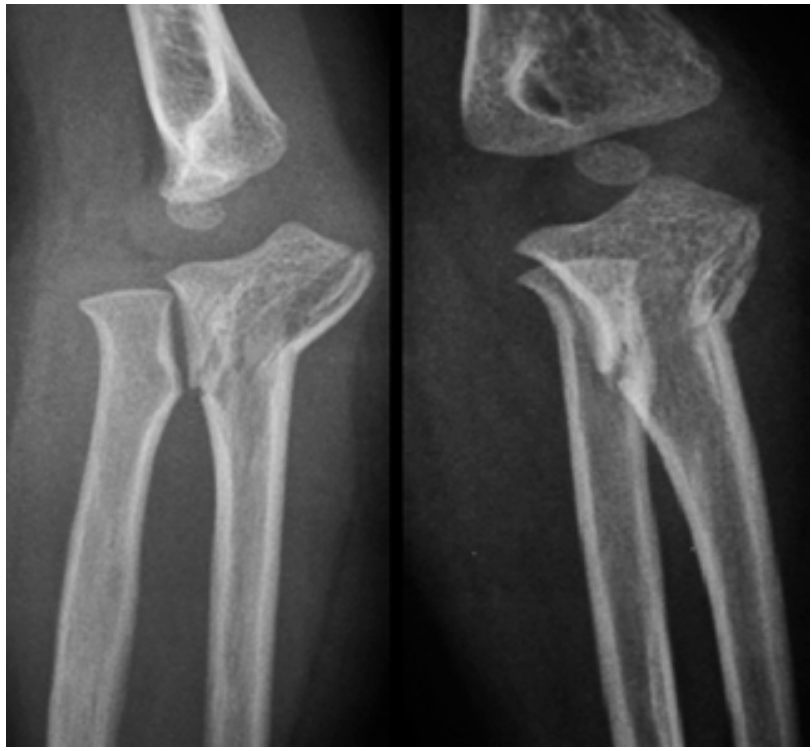

Şekil 17. Deplase parçalı olekranon proksimal kırı̆ıı ile birlikte radius başının öne çıkığı (Bado Tip I, Monteggia kırıkı çıkığı).

\section{GALEAZZI KIRIKLI ÇIKIKLARI}

Galeazzi kırıkları, distal radius kırığına eşlik eden distal radyoulnar eklem çıkığı veya çocuklarda genelde ulna distal fizis deplase yaralanması olarak tanımlanır (Şekil 20). Çok nadir görülen ve acil servislerde atlanma olasılığı olan yaralanmalardır. On yaş üzeri daha sık görülür. Dirsek ekstansiyonda el üzerine düşme ile yaralanma oluşur. Önkolun pronasyon ve supinasyonu kırıkta ve ulnada açılanmanın yönünü belirler. Önkol pronasyonda ise ulna distali dorsale deplase olur ve radiusta apeksi dorsalde olan açılanma görülür. Düşme esnasında önkol supinasyonda ise volare doğru deplase radius distal kırı̆̆ı oluşur ve ulna distali de volare deplase olur. ${ }^{[11]}$ 


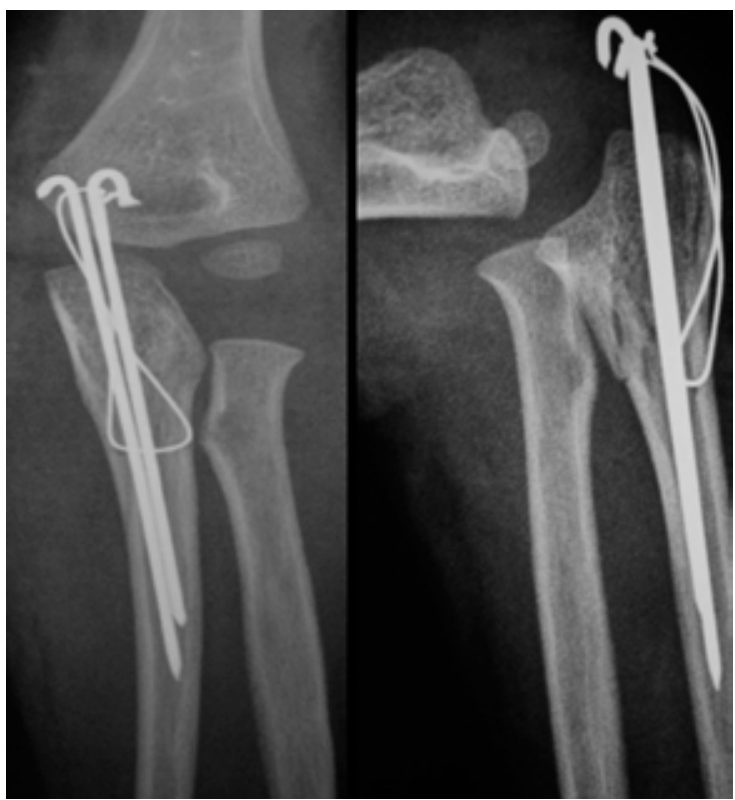

Şekil 18. Deplase parçalı olekranon proksimal kırığı ile birlikte radius başının öne çıkığının açık redüksiyon ve gergi bandı yöntemiyle tedavisi sonrası.

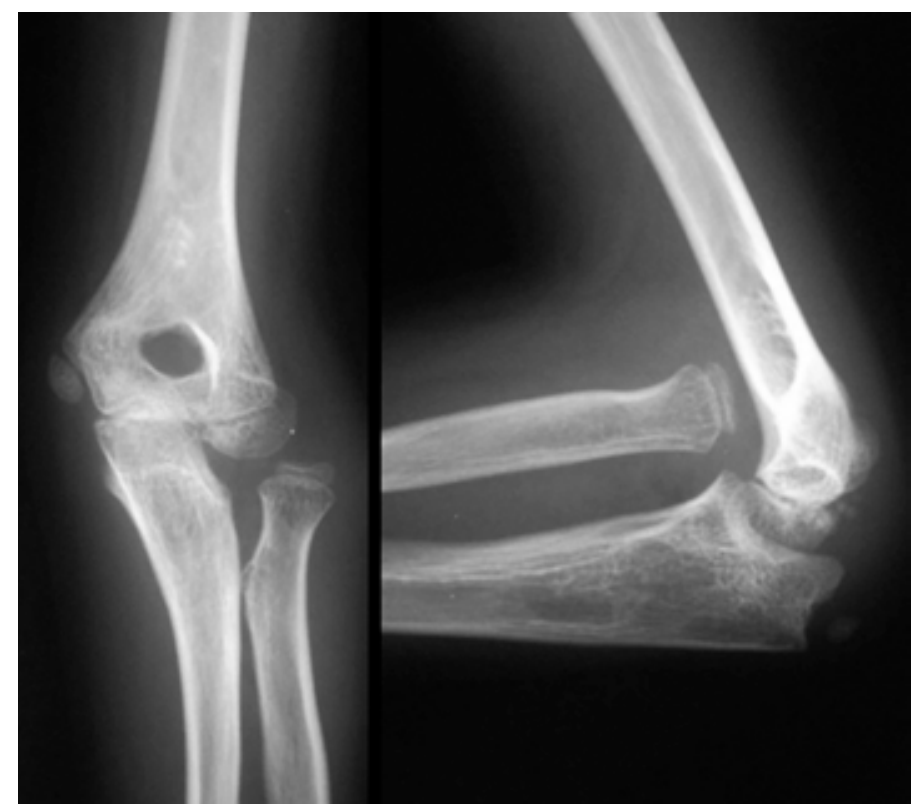

Şekil 19. Atlanmış Monteggia kırıklı çıkığına bağlı radius başının kronik çıkığı.

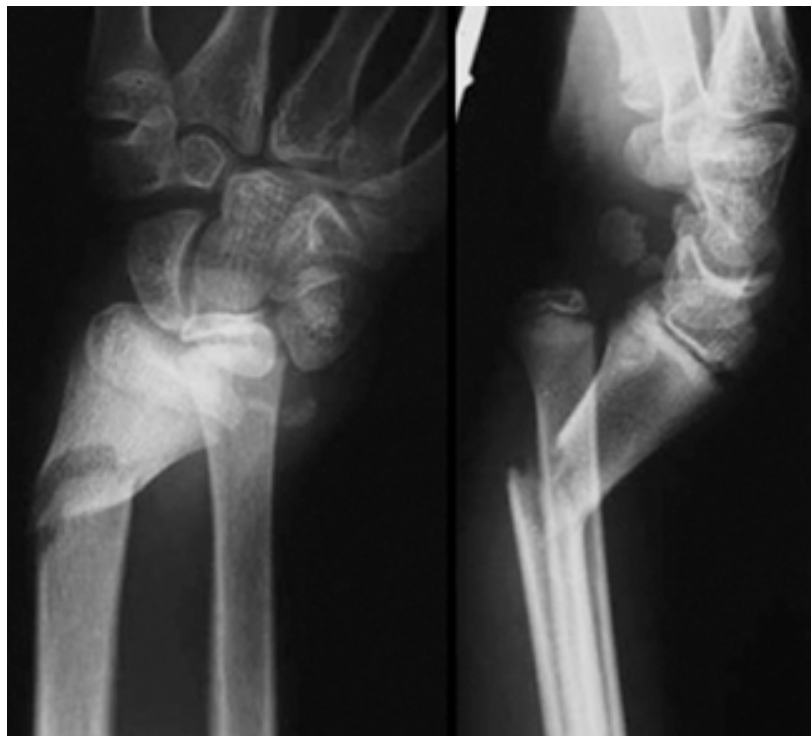

Şekil 20. Galeazzi kırıklı çıkı̆̆ı.

Hasta genelde el bileği ve önkolda ağrı, şişlik, deformite ile başvurur. Ulna stiloidi bazen belirgin olabilir. El bileği hareketleri kısıtlıdır ve krepitasyon alınabilir. Klinik şikâyetlerin hafif fakat ulna stiloidinin belirgin olduğu olgularda mutlaka karşı el bileği de incelenmelidir.

íki yönlü el bileği grafileri ile tanı kolaylıkla konulabilir. Distal ulna deplasmanının yönünü görmek için "gerçek el bileği yan grafisi” çekilmelidir.
Kapalı redüksiyon ve önkol supinasyonda, dirsek fleksiyonda uzun kol alçı ile 10 yaşına kadar çocuklarda oldukça başarılı sonuçlar elde edilebilir. Ancak, kontrol grafisinde distal radyoulnar eklem redüksiyonu iyi değerlendirilmelidir. ${ }^{[11]}$ Redüksiyonun başarısız olduğu olgularda cerrahi tedavi endikasyonu vardır. Radius elastik titanyum çivileriyle veya plak-vida ile tespit edilebilir (Şekil 21). ${ }^{12]}$ Distal radyoulnar eklem (DRUE) redüksiyonunda periost veya "ekstansör karpi ulnaris tendonu" sıkışarak sıkıntı yaratabilir. Bu durumlarda açık redüksiyon gereklidir.

En önemli komplikasyonu kronik DRUE instabilitesidir.

\section{TRAVMATIK KALÇA ÇIKIKLARI}

Travmatik kalça çıkıkları çocuklarda kalça kırıklarından daha sık görülen yaralanmalardır. Genelde arkaya çıkık görülür (Şekil 22). Nadiren öne çıkık görülebilir (Şekil 23). On yaş altı düşme ve spor yaralanmaları, 10 yaş üstü trafik kazaları gibi yüksek enerjïle oluşan ve prognozu tedaviden bağımsız olan yaralanmalardır. Saf kalça çıkıkları olabildiği gibi, femur başı, boynu, asetabulum kırıkları ve femur üst uç fizis yaralanmaları eşlik edebilir. ${ }^{[13]}$

Hastalar kalça ağrısı, bacağının üstüne basamama ve bacakta deformite ile karşımıza gelirler. En sık görülen arkaya çıkıkta; alt ekstremite hafif fleksiyonda, adduksiyonda ve iç rotasyonda durur. Bacak kısalmış gibi görülür. Öne kalça çıkıklarında ise alt ekstremite hafif 


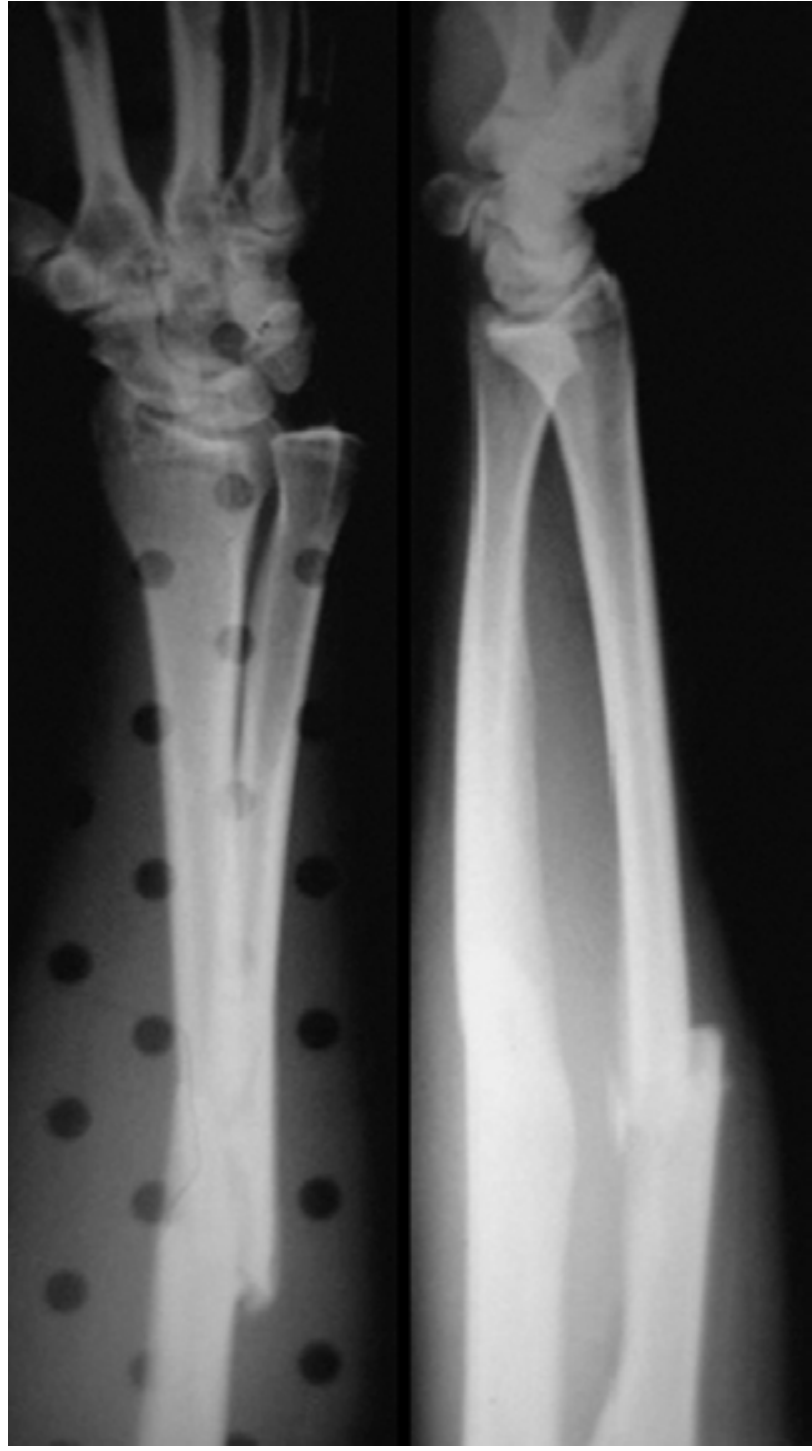

Şekil 21. Radius ve ulna cisim proksimal kırı̆̆ı ile birlikte DRUE çıkığı (Galeazzi kırı̆̆ı).

fleksiyonda, abduksiyonda ve dış rotasyondadır. Nadir de olsa siyatik veya gluteal sinir yaralanması görülebilir. Mutlaka ayrıntılı nörolojik muayene yapılmalıdır.

íki yönlü kalça grafisi ile tanı genelde kolaylıkla konur. Ancak, şüpheli ve kırığın eşlik edebileceği durumlarda bilgisayarlı tomografi (BT) ile tanı konfirme edilmelidir. Redüksiyon manevrası ile çıkık redükte edildikten sonra şüpheli durumlarda (eklem mesafesinde genişleme varsa, konsantrik redüksiyon yoksa, eklem uyumu bozuksa, osteokondral parça varsa) BT ile redüksiyonun kalitesi değerlendirilmelidir (Şekil 24 ve 25).

Hastaların çoğu genellikle genel anestezi altında kolaylıkla redükte edilirler. Konsantrik redüksiyon

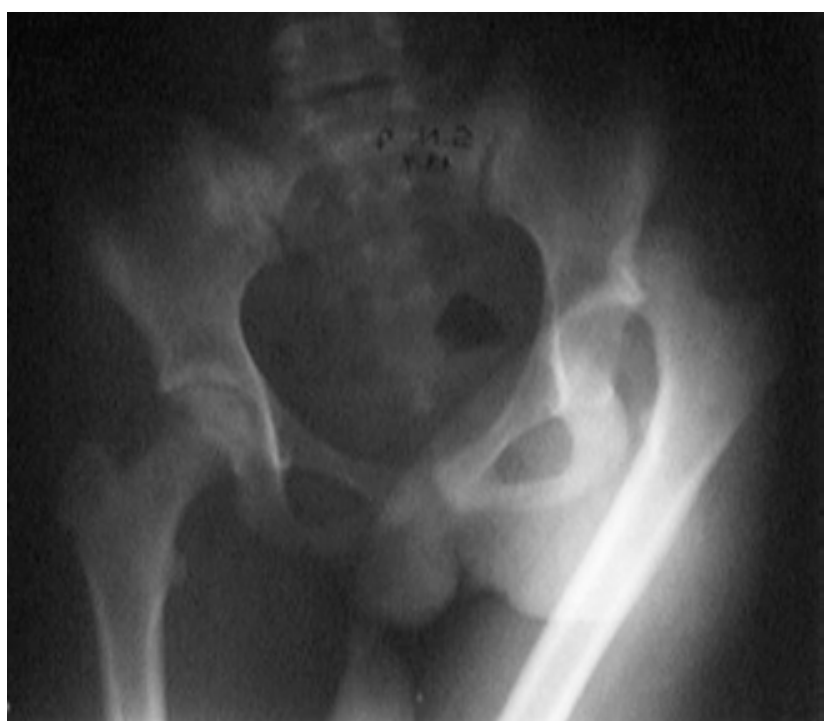

Şekil 22. Arkaya travmatik kalça çıkı̆̆ı.

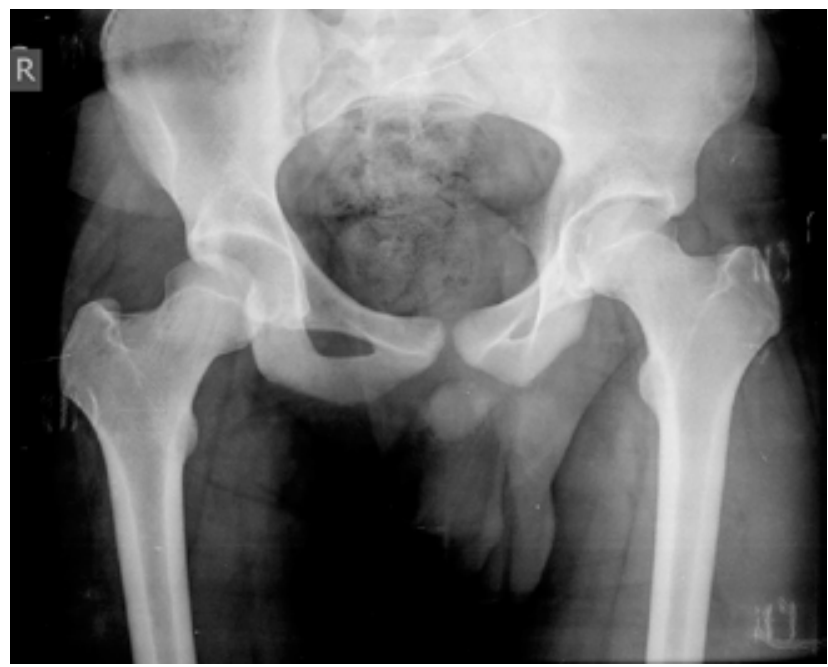

Şekil 23. Öne travmatik kalça çıkı̆̆ı.

elde edilemiyorsa, eklem içi parça varsa, instabil asetabular dudak kırığı varsa, açık redüksiyon gerekir (Şekil 26). Bazen yumuşak doku interpozisyonu redüksiyona engel olabilir (Şekil 27 ve 28). Redüksiyon sonrası bacak abduksiyonda pelvi-pedal alçı uygulanır. On yaş altı dört hafta, 10 yaş üstü 6-12 hafta tam yüklenme verilmemelidir.

Travmatik kalça çıkı̆̆ının en önemli komplikasyonu, femur başı avasküler nekrozudur (Şekil 29); \%0-15 arası görülür. Erken yapılan redüksiyon, başlangıç travmasının düşük enerjisi ve yaşın küçük olması avasküler nekroz insidansını düşüren nedenlerdir. Diğer komplikasyonlar; geç post-travmatik osteoartroz, coxa magna, heterotopik ossifikasyon ve tekrarlayıcı çıkıklardır. [14] 


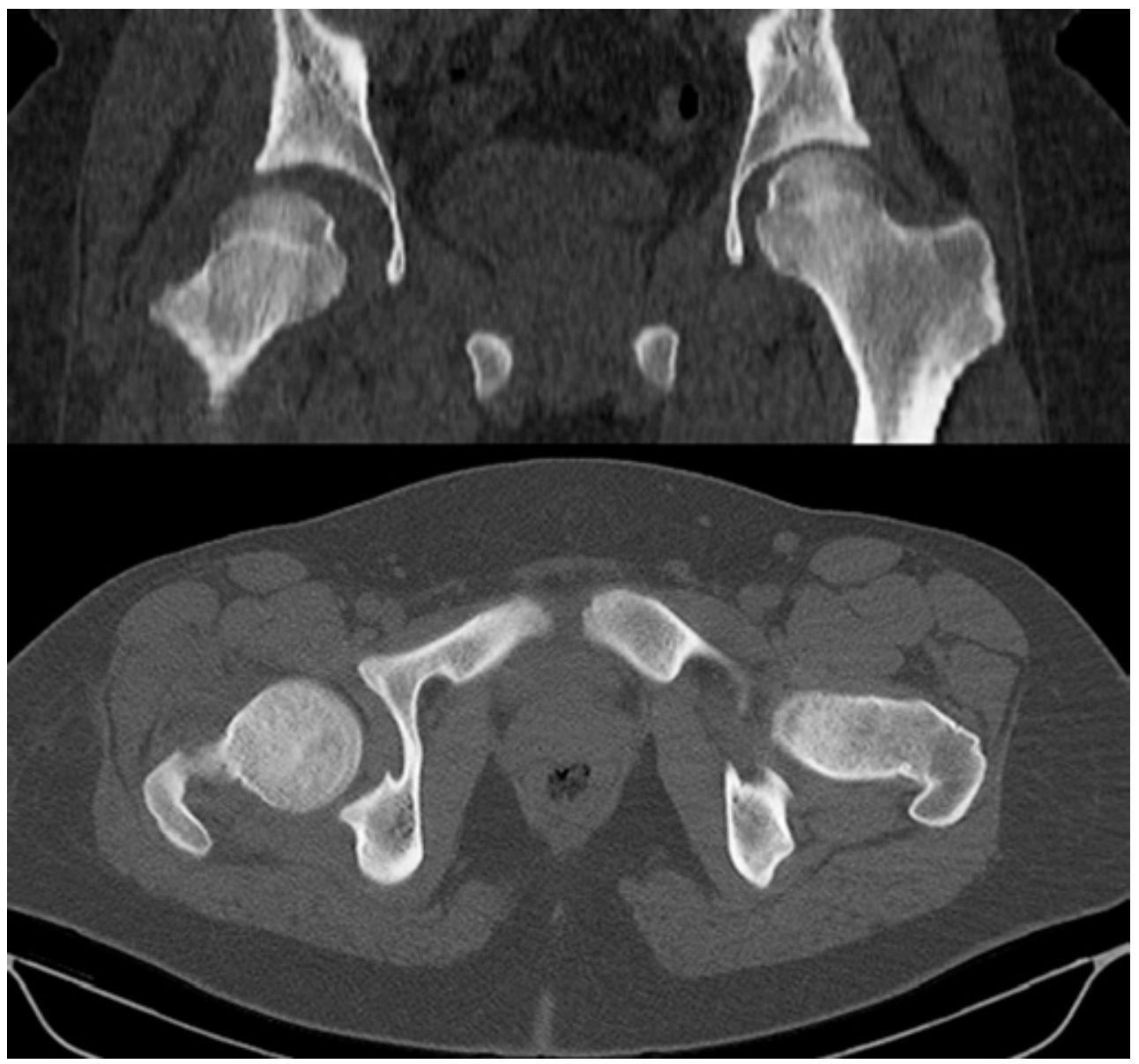

Şekil 24. Öne travmatik kalça çıkığında BT kesitleri.

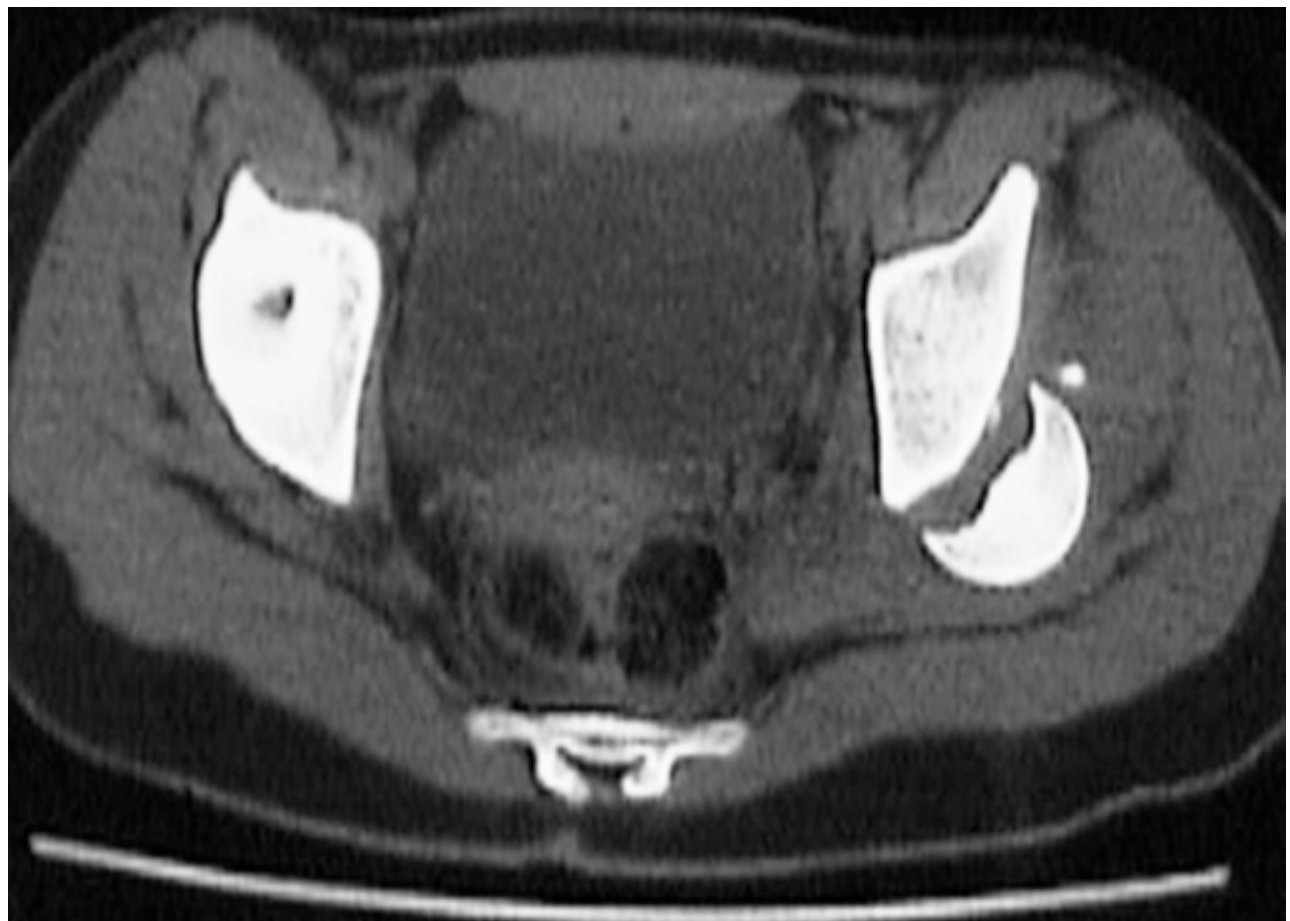

Şekil 25. Arkaya kalça çıkığı ile birlikte Delbet Tip I kırıklı hastanın BT görüntüsü. 


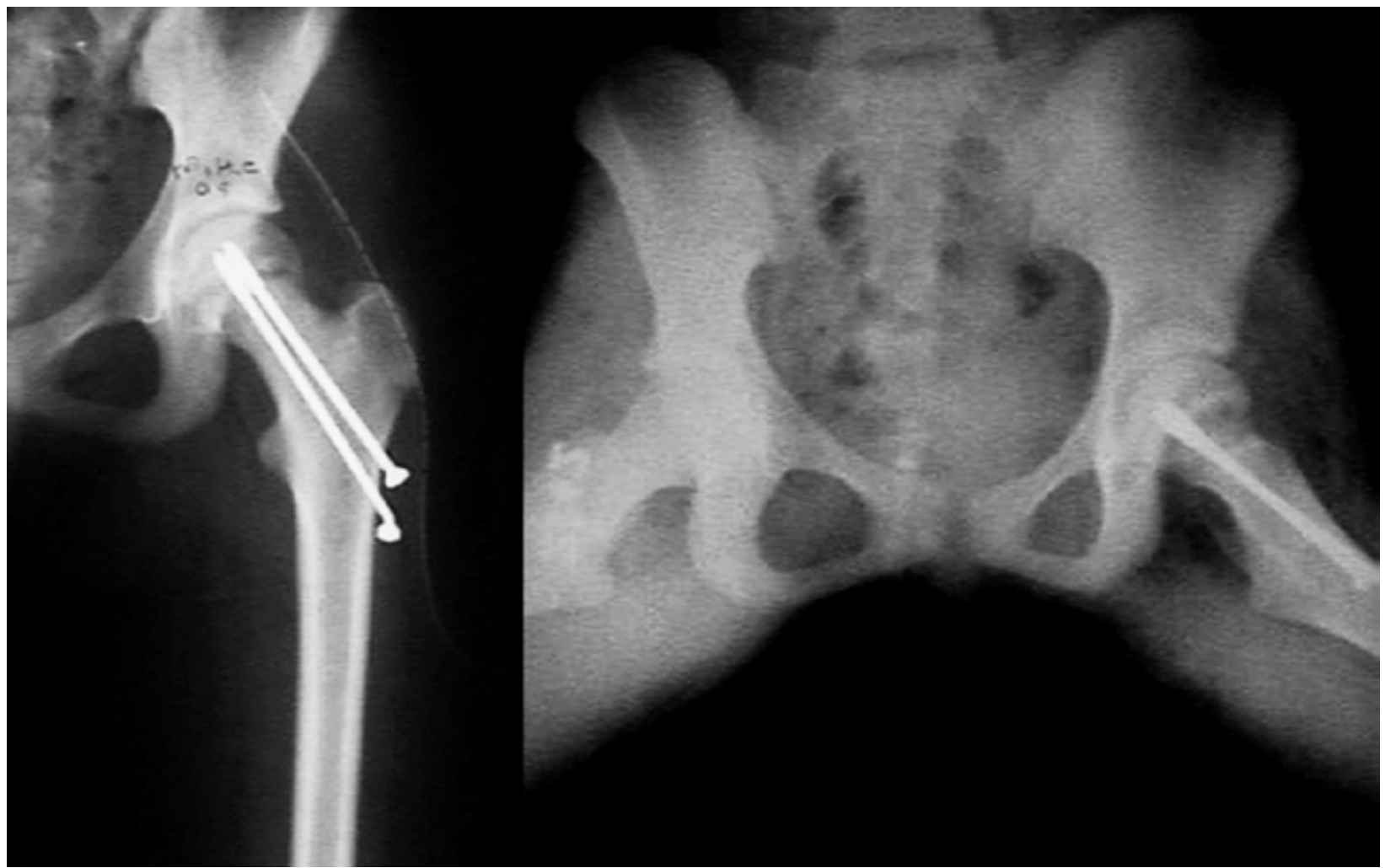

Şekil 26. Delbet Tip I arkaya kırıklı çıkığı olgunun açık redüksiyon ve internal tespit sonrası ön-arka ve yan grafisi.

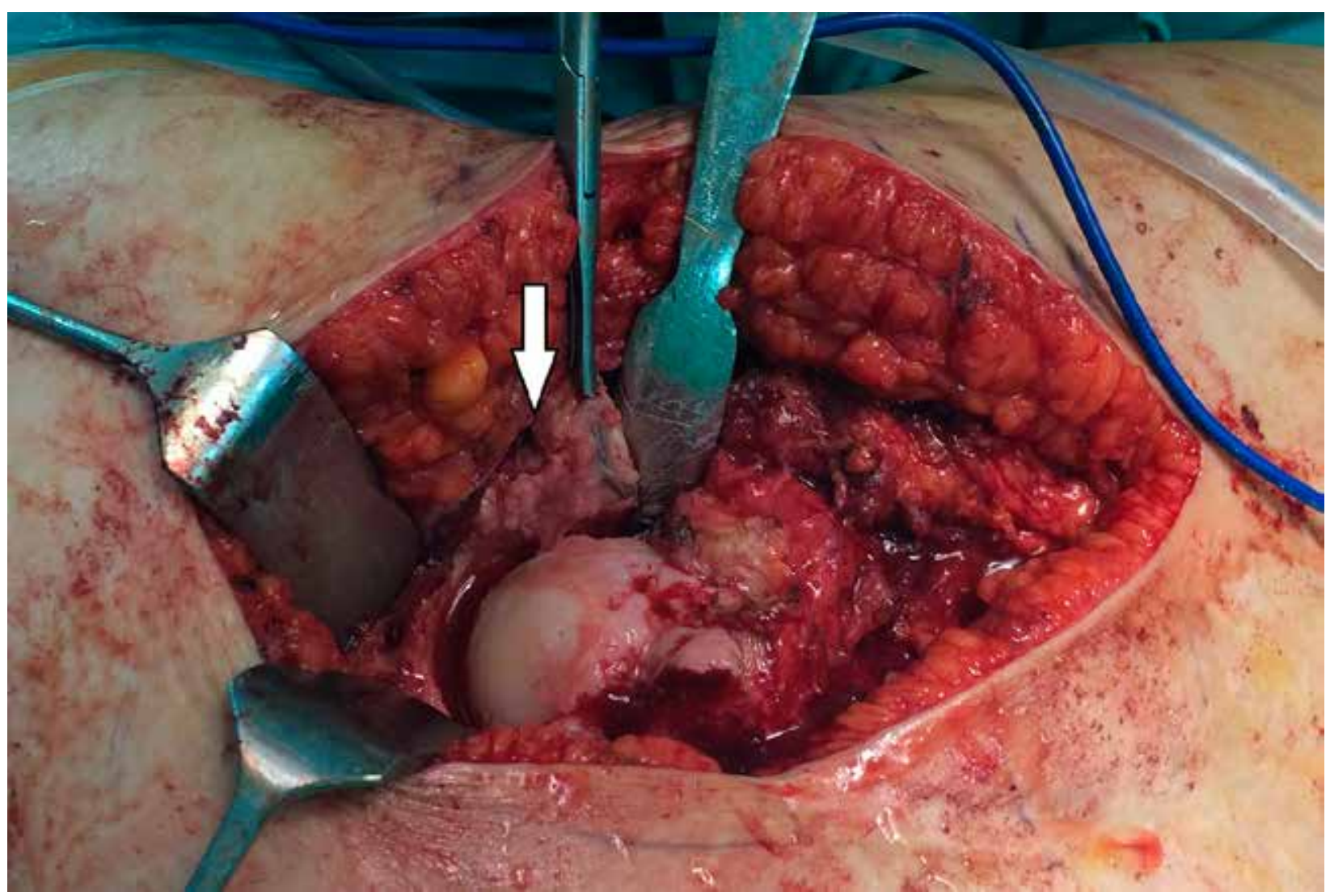




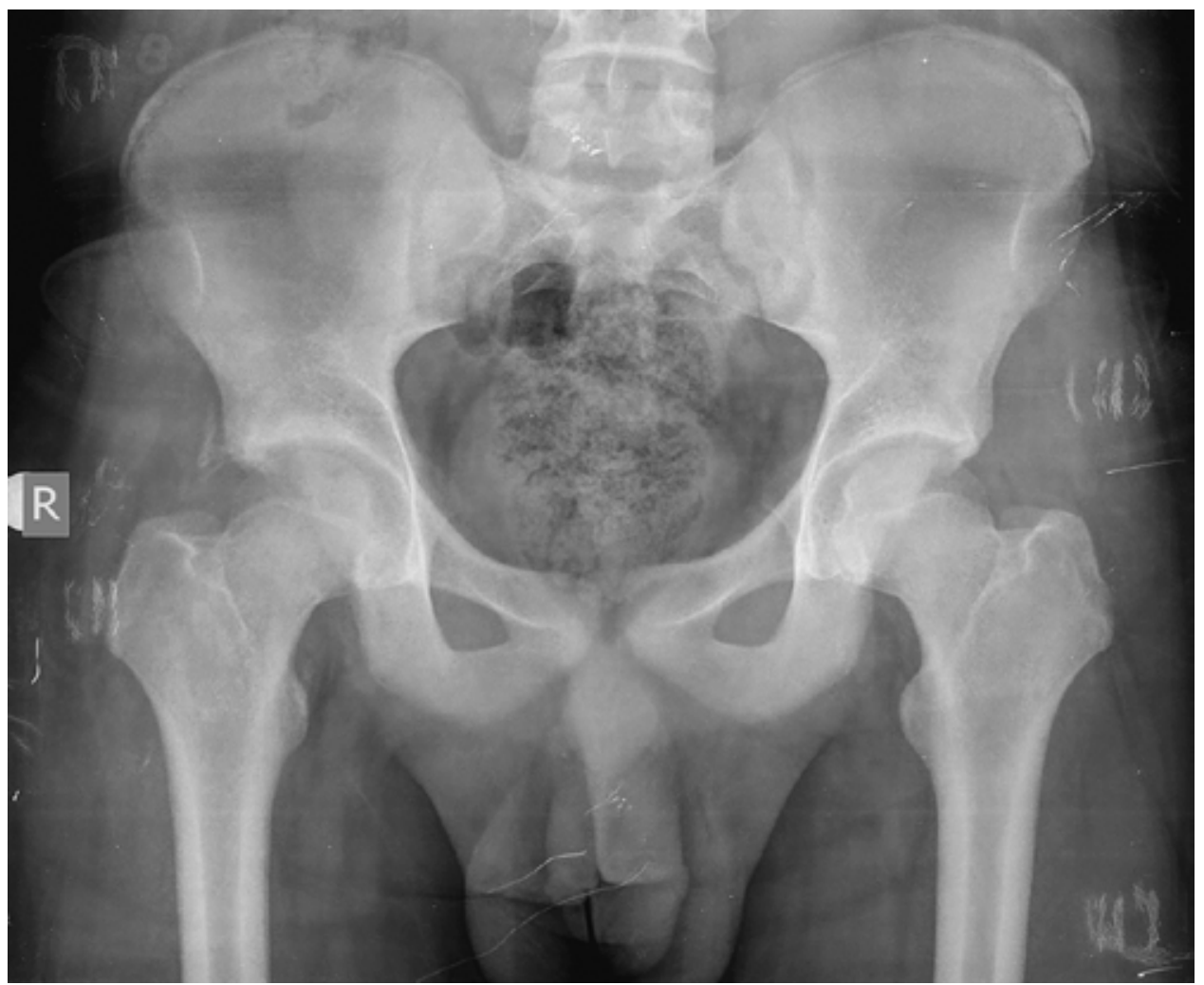

Şekil 28. Sağ travmatik kalça çıkığı nedeniyle açık redüksiyon uygulanan hastanın ameliyat sonrası 45. gün ön-arka grafisi.

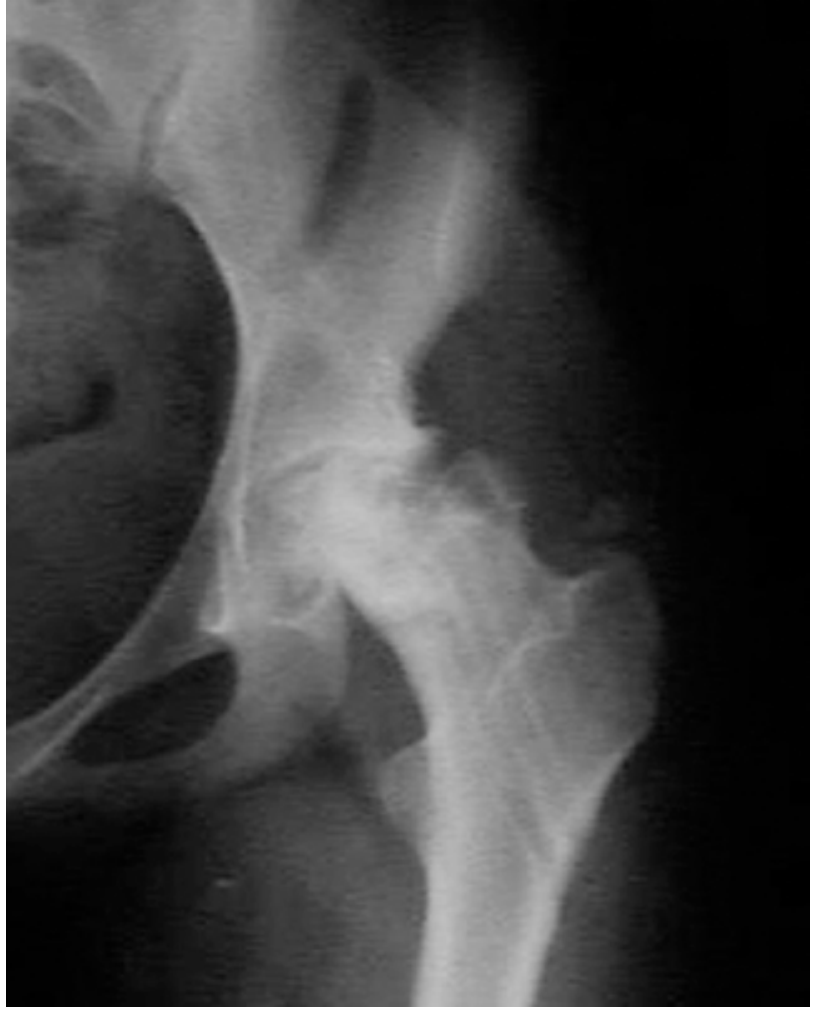

Şekil 29. Delbet Tip I yaralanma sonrası açık redüksiyon ve kırığa vida ile tespit uygulanması sonrası birinci yılda gelişen femur başının avasküler nekrozu.

\section{AKUT TRAVMATIK PATELLAR ÇIKIKLAR VE OSTEOKONDRAL KIRIKLAR}

Akut travmatik patella çıkıklarında patella çoğunlukla laterale kayar ve hastalar genelde diz fleksiyonda kilitli halde acil servise gelirler. Çıkık sıklıkla kendiliğinden redükte olur veya basit bir ekstansiyon manevrası ile redükte edilebilir. Diz içinde effüzyon, hassasiyet ve lateral femoral kondil üzerinde ve mediyal patello-femoral bölgede ağrı vardır. Yüzde 15 olguda patellar çıkığa, patella osteokondral yaralanması eşlik eder (Şekil 30). Şüpheli olgularda mutlaka BT ile ayrıntılı inceleme yapılmalıdır (Şekil 31). Bu parçalanma, patellanın mediyal fasetinden veya patella ile karşı karşıya gelen femur lateral kondilinden kaynaklanır ${ }^{[15]} ; 1,5 \mathrm{~cm}$ 'den küçük parçaların tespiti oldukça güçtür. İhmal edilmiş veya bu tip küçük parçaların çıkarılması gerekir. ilk çıkık sonrası primer olarak bağ onarımının sonuçları, konservatif olarak tedavi edilenlerden daha iyi değildir. Parçanın büyük olduğu olgularda, yalnızca başsız kompresyon vidalarıyla tespit tercih edilmelidir (Şekil 32). Eklem hareket açıklı̆ının kazanılması için yoğun fizik tedavi gerekir (Şekil 33). Dizilim bozukluğu, malrotasyon ya da tekrarlayan çıkık varsa, mediyal patellofemoral bağ (MPFL) tamiri ve gerekiyorsa augmentasyon ameliyatları yapılmalıdır. ${ }^{[15]}$ 


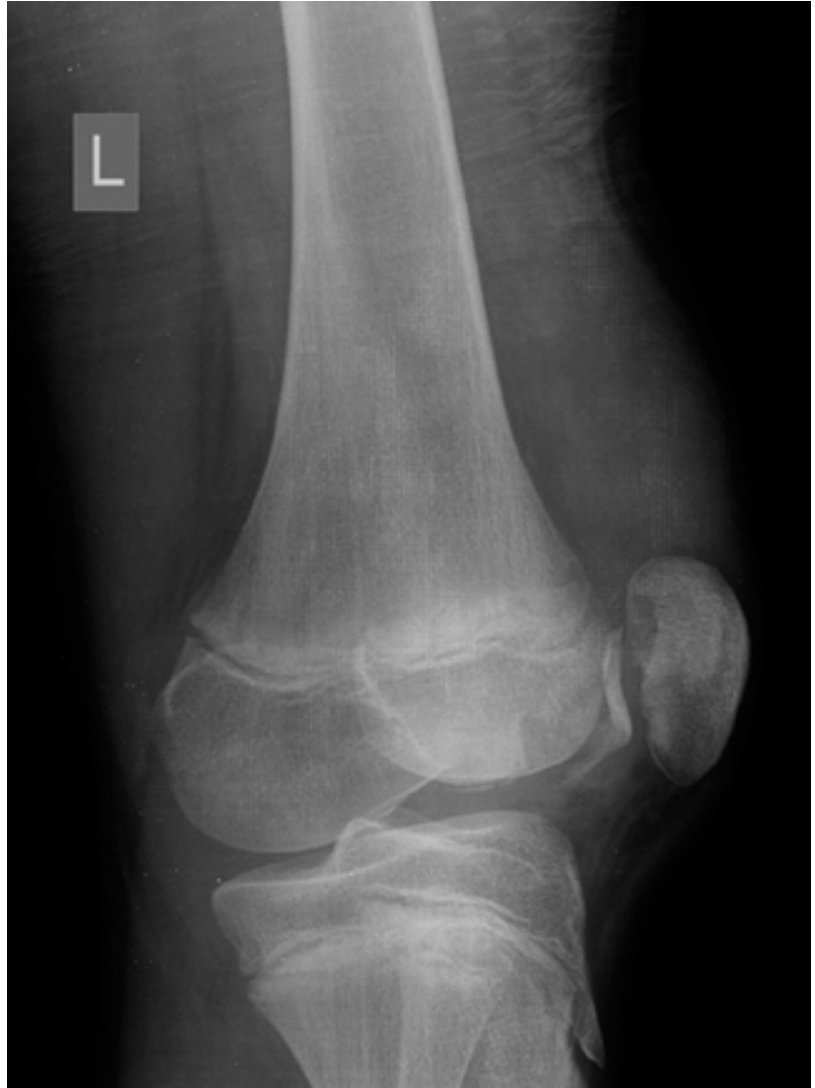

Şekil 30. Akut patellar çıkık ve osteokondral kırıklı adolesan hasta.

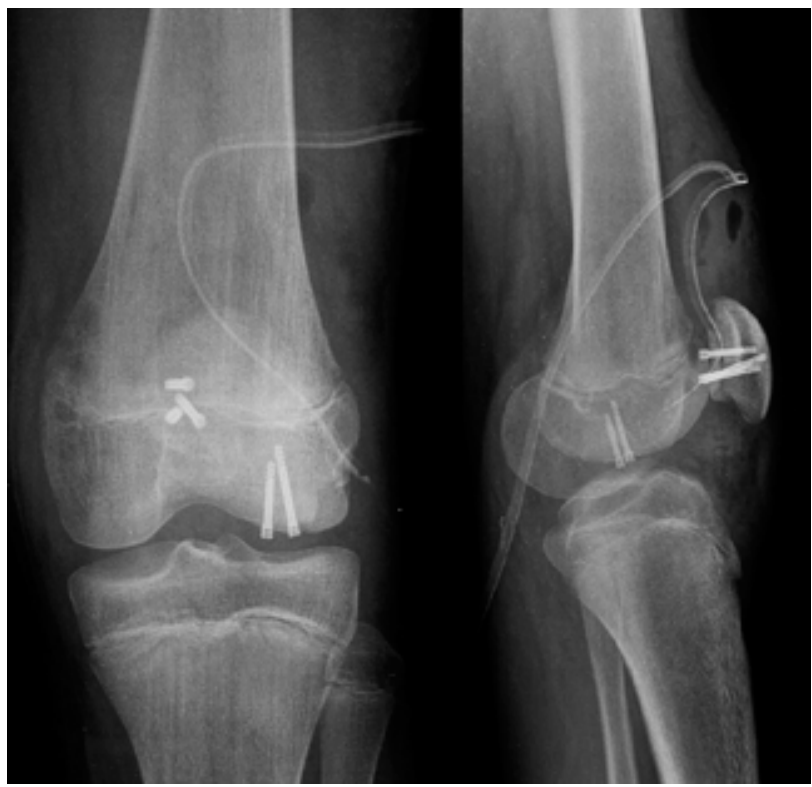

Şekil 32. Akut travmatik patella dislokasyonu ve osteokondral kırık açık redüksiyon ve başsız vidalarla internal tespiti sonrası.

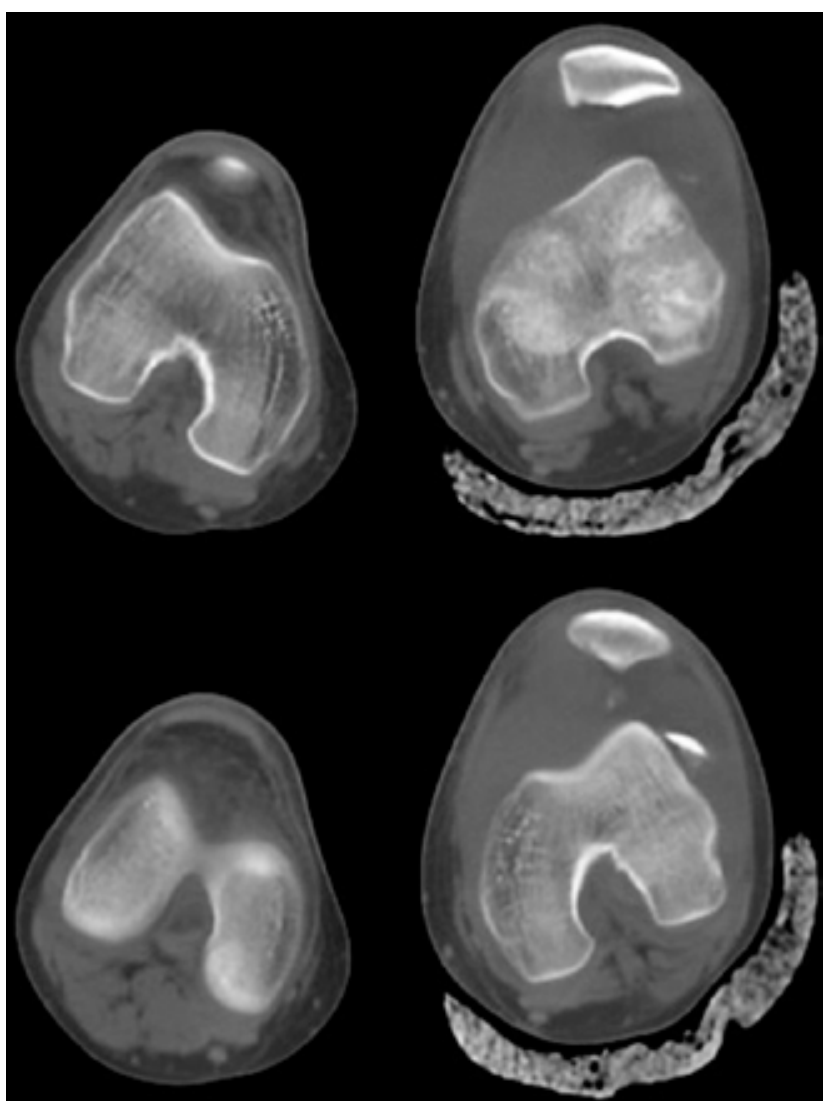

Şekil 31. Akut travmatik patellar çıkıkta, çıkık ve osteokondral parçanın BT ile görünüşü.

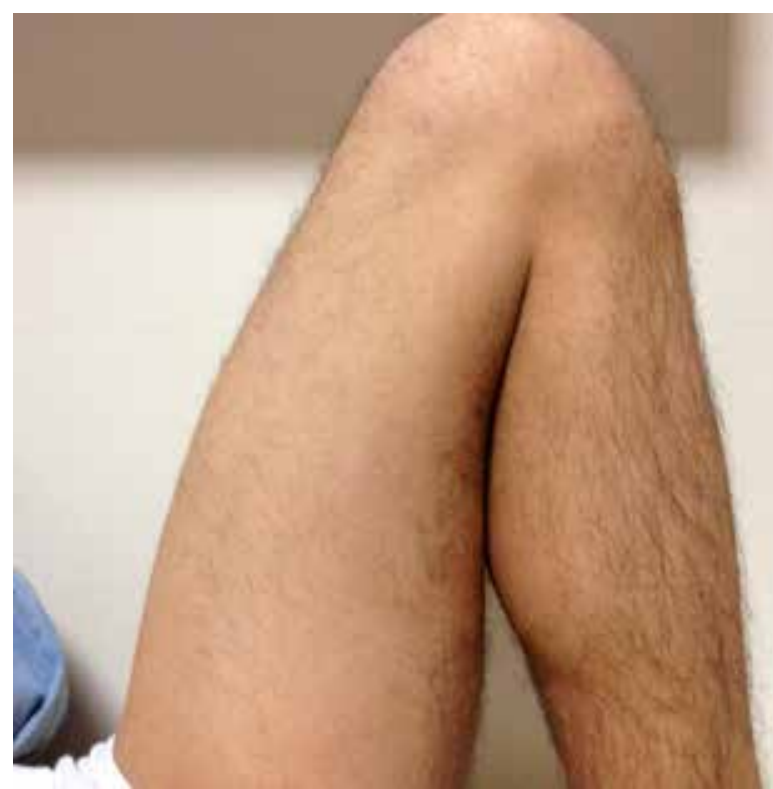

Şekil 33. Akut patellar çıkık ameliyatı sonrası hastanın diz fleksiyon hareket açıklığı tam olarak sağlandı. 


\section{KAYNAKLAR}

1. Halsey MF. Pediatric pulled elbow injury: more common and recurrent than you think. Acta Pediatr 2019;107(11):1850. Crossref

2. Kocher MS, Waters PM, Micheli LJ. Upper extremity injuries in the paediatric athlete. Sports Med 2000;30(2):117-35. Crossref

3. Olds M, Donaldson K, Ellis R, Kersten P. In children 18 years and under, what promotes recurrent shoulder instability after traumatic anterior shoulder dislocation? A systematic review and meta-analysis of risk factors. Br J Sports Med 2016;50(18):1135-41. Crossref

4. Leroux T, Ogilvie-Harris D, Veillette C, Chahal J, Dwyer T, Khoshbin A, Henry P, Mahomed N, Wasserstein D. The epidemiology of primary anterior shoulder dislocations in patients aged 10 to 16 years. Am J Sports Med 2015;43(9):2111-7. Crossref

5. Sofu H, Gursu S, Camurcu Y, Yildirim T, Sahin V. Pure elbow dislocation in the paediatric age group. Int Orthop 2016;40(3):541-5. Crossref

6. Satake $Y$, Tomori $Y$, Sawaizumi T, Nanno M, Kodera N, Takai S. Irreducible Elbow Fracture and Dislocation due to Incarceration of the Medial Epicondyle of the Humerus in a Child. J Nippon Med Sch 2018;85(1):60-65. Crossref

7. Lu X, Yan G, Lu M, Guo Y. Epidemiologic features and management of elbow dislocation with associated fracture in pediatric population. Medicine (Baltimore) 2017;96(48):e8595. Crossref
8. Pace GI, Hennrikus WL. Fixation of Displaced Medial Epicondyle Fractures in Adolescents. J Pediatr Orthop 2017;37(2): e80-e82. Crossref

9. Bae DS. Successful Strategies for Managing Monteggia Injuries. J Pediatr Orthop 2016;36 Suppl 1:S67-70. Crossref

10. Bado JL. The Monteggia lesion. Clin Orthop Relat Res 1967;50(1):71-86. Crossref

11. Eberl R, Singer G, Schalamon J, Petnehazy T, Hoellwarth ME. Galeazzi lesions in children and adolescents: treatment and outcome. Clin Orthop Relat Res 2008;466(7):1705-9. Crossref

12. Wall L, O'Donnell JC, Schoenecker PL, Keeler KA, Dobbs MB, Luhmann SJ, Gordon JE. Titanium elastic nailing radius and ulna fractures in adolescents. J Pediatr Orthop B 2012;21(5):482-8. Crossref

13. Başaran SH, Bilgili MG, Erçin E, Bayrak A, Öneş HN, Avkan MC. Treatment and results in pediatric traumatic hip dislocation: case series and review of the literature. Ulus Travma Acil Cerrahi Derg 2014;20(6):437-42. Crossref

14. Sulaiman AR, Munajat I, Mohd EF. Outcome of traumatic hip dislocation in children. J Pediatr Orthop B 2014;23(2):2045. Crossref

15. Hasler CC, Studer D. Patella instability in children and adolescents. EFORT Open Rev 2016;1(5):160-6. Crossref 